EUROPEAN CENTRAL BANK

EUROSYSTEM

ECB LAMFALUSSY FELLOWSHIP PROGRAMME

\section{WORKING PAPER SERIES}

NO 934 / SEPTEMBER 2008

\title{
BANK MERGERS
}

\section{AND LENDING RELATIONSHIPS}

by Judit Montoriol-Garriga

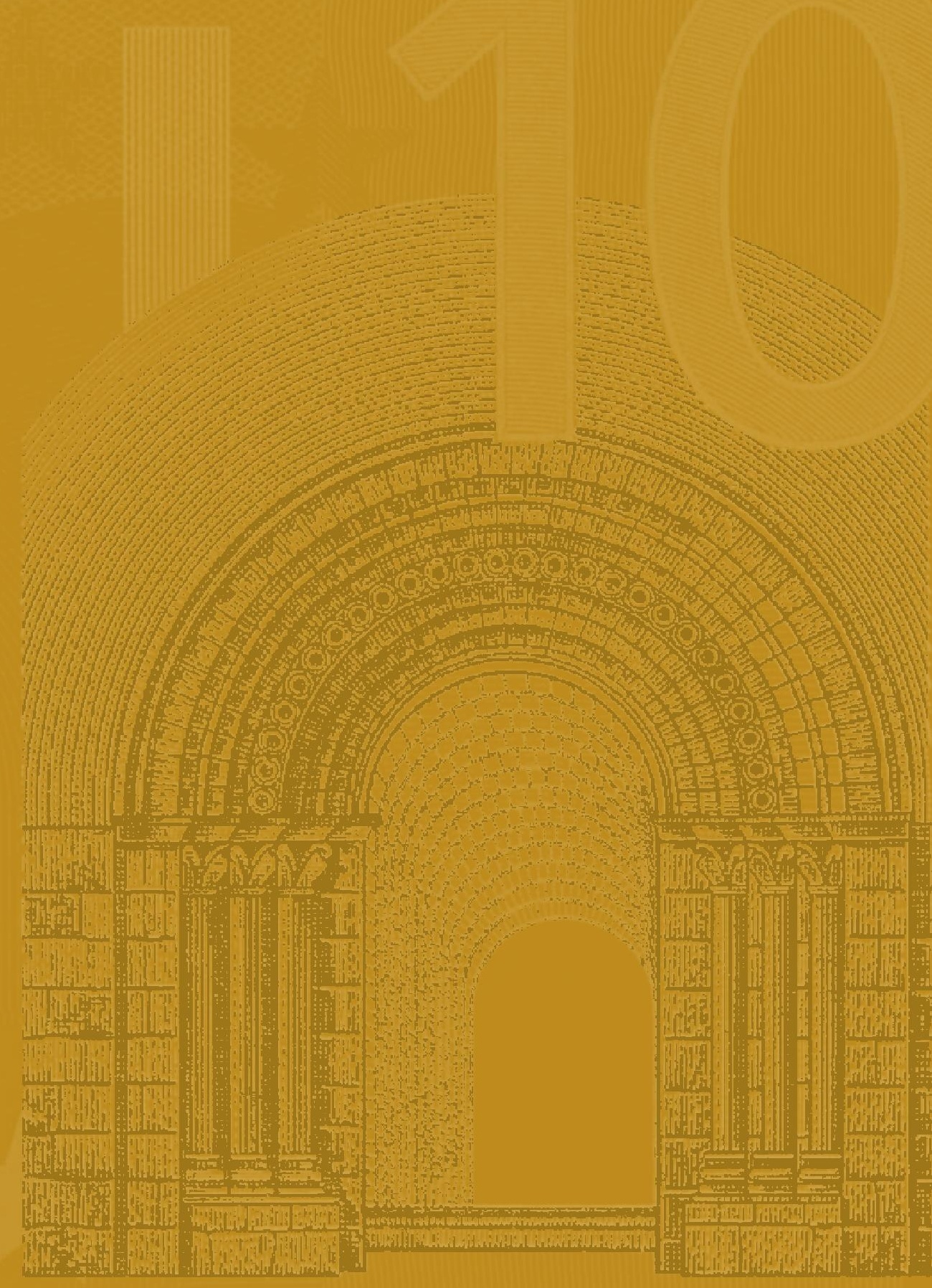


EUROSYSTEM

\section{WORKING PAPER SERIES}

NO 934 / SEPTEMBER 2008

ECB LAMFALUSSY FELLOWSHIP PROGRAMME

\section{BANK MERGERS AND LENDING RELATIONSHIPS '}

by Judit Montoriol-Garriga ${ }^{2}$
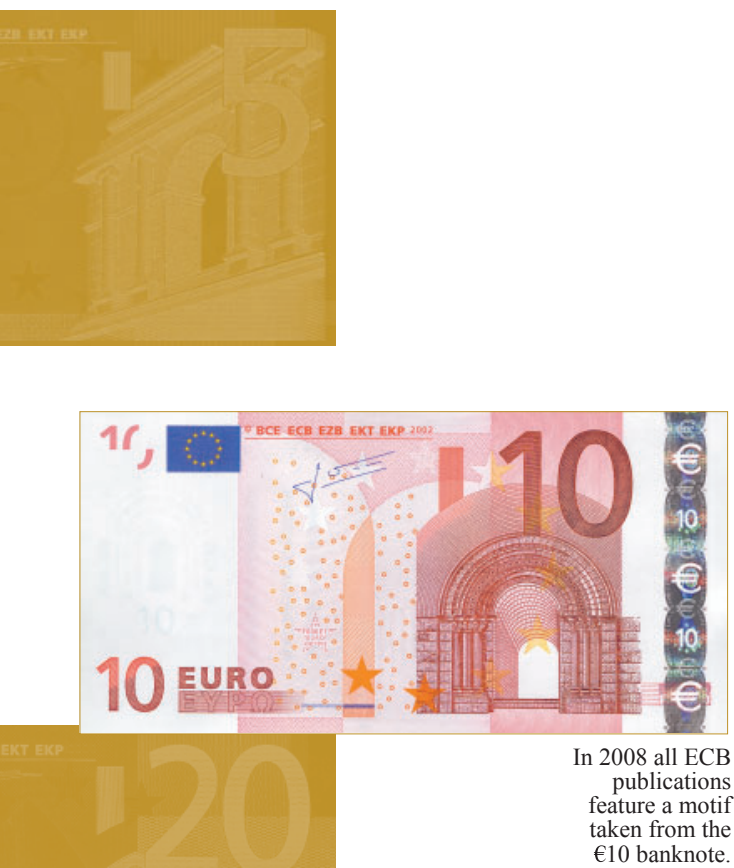

This paper can be downloaded without charge from http://www.ecb.europa.eu or from the Social Science Research Network electronic library at http://ssrn.com/abstract_id=1240861.

I I would like to thank seminar participants at Federal Reserve Bank of Boston, Universitat Autònoma de Barcelona and an anonymous referee for helpful comments and discussions. Excellent research assistance was provided by Nicholas Kraninger and Jonathan Larson. I am grateful to Esteban Lafuente for his help with the data. All remaining errors are mine. This paper has been prepared by the author under the Lamfalussy Fellowship Programme sponsored by the European Central Bank. Any views expressed are only those of the author and do not necessarily represent the views of the ECB, the Eurosystem, the Federal Reserve Bank of Boston or the Federal Reserve System. 2 Federal Reserve Bank of Boston, 600 Atlantic Avenue, Boston, MA 022 I0, USA. Tel.+16179733191; e-mail: Judit.Montoriol-Garriga@bos.frb.org 


\section{Lamfalussy Fellowships}

This paper has been produced under the ECB Lamfalussy Fellowship programme. This programme was launched in 2003 in the context of the ECB-CFS Research Network on "Capital Markets and Financial Integration in Europe". It aims at stimulating highquality research on the structure, integration and performance of the European financial system.

The Fellowship programme is named after Baron Alexandre Lamfalussy, the first President of the European Monetary Institute. Mr Lamfalussy is one of the leading central bankers of his time and one of the main supporters of a single capital market within the European Union.

Each year the programme sponsors five young scholars conducting a research project in the priority areas of the Network. The Lamfalussy Fellows and their projects are chosen by a selection committee composed of Eurosystem experts and academic scholars. Further information about the Network can be found at http://www.eu-financialsystem.org and about the Fellowship programme under the menu point "fellowships".

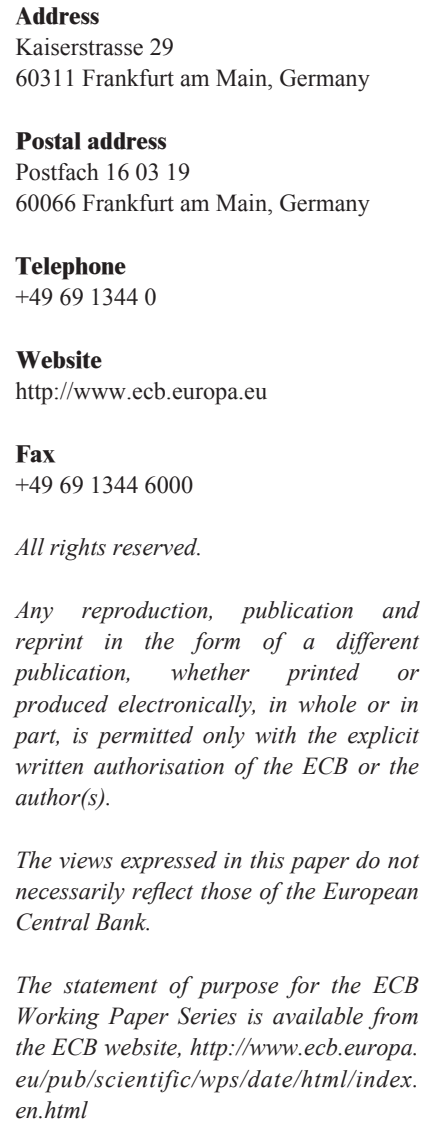




\section{CONTENTS}

Abstract

Non-technical summary

1 Introduction

2 Banking consolidation in Spain

3 Data

3.1 Sample

3.2 Definition of relevant market

4 The effect of bank mergers on termination and initiation of lending relationships

4.1 Termination of lending relationships

4.2 Initiation of lending relationships

5 The effect of bank mergers on average interest rates

5.1 The basic model and definition of variables

5.2 Main results

5.3 Temporary and permanent effects

5.4 Target versus acquirer borrowers

5.5 Overlap borrowers

5.6 Continuing, terminating and switching lending relationships

5.7 Borrower size and age

5.8 Bank size and ownership form

5.9 In-market mergers, out-of-market mergers and market concentration

5.10 Does selection explain the reduction in interest rates?

6 Conclusion and implications for

European banking market integration

References

Tables

European Central Bank Working Paper Series 


\begin{abstract}
This paper analyzes the effects of bank mergers on bank-firm relationships. Using matched bank-firm level data, I find that mergers disrupt lending relationships, specially to small borrowers of target banks. However, I find significant positive effects of mergers for borrowers that continue the lending relationship with the consolidated bank. On average, consolidated banks reduce loan interest rates. The most beneficial mergers from the borrower point of view are those involving two large banks and commercial banks. While the reduction in interest rates is larger when the acquirer and the target have some market overlap, the decline is much smaller when there is a significant increase in local banking market concentration.
\end{abstract}

JEL Classification: G21, G34

Keywords: Banking consolidation, Lending relationships, Small business lending. 


\section{Non-technical summary}

During the last decade, a consolidation process of the European banking industry has been under way. In the period between January 1996 and December 2005 European banks spent $€ 682 \mathrm{bn}$ ( 816 deals) acquiring banking businesses throughout the world. Far of being an isolated fact, almost everywhere banks have been getting bigger through mergers and acquisitions (M\&A). For instance, in the U.S. the ten biggest commercial banks control $49 \%$ of the country's banking assets, up from $29 \%$ a decade ago. This market concentration has raised the concern among policy makers, regulators and academics that small businesses may find it harder to obtain finance from larger and more complex financial institutions.

This paper analyzes the potential positive and negative effects of bank mergers to small business borrowers: Do bank mergers harm or benefit firm borrowers? The study focuses on small and medium enterprises (SMEs) for two reasons: first, banks are especially important for SMEs as they represent these firms' principal source of external finance, and second, because the value of relationship lending, which is based on close ties between banks and borrowers, is likely to be higher for these firms. Given the importance of SMEs to create employment and foster innovation, any impact of bank mergers on SMEs may have important policy implications.

One argument commonly used in favor of mergers in banking, as in many other industries, is the pursuit of economies of scale and scope and increased diversification opportunities. Borrowers will benefit to the extent that consolidated banks pass on efficiency gains to them. However, bank mergers increase market concentration. Borrowers will be harmed to the extent that consolidated banks exert their market power. In addition to this traditional merger trade-off, small business lending is characterized by the role of lenders on gathering and generating information about borrowers through long lasting lending relationships that help overcome informational asymmetries in credit markets. A priori, bank mergers could foster or inhibit lending relationships.

This paper provides evidence on the costs and benefits of bank mergers to small businesses using a sample of Spanish firms. On one hand, mergers are harmful to small businesses because lending relationships are more likely to be disrupted following a merger. Small borrowers of target banks have a higher probability of having terminated a relationship with the consolidated bank. Moreover, small borrowers find it harder to start new lending relationship with consolidated banks. In sum, the higher termination rate for existing borrowers is not compensated with a higher initiation rate of new lending relationships with small business after the merger.

On the other hand, continuing borrowers benefit from mergers in terms of reduced loan rates. Small and young firms enjoy the highest decline in interest rates. The most beneficial mergers from the borrower point of view are those involving two large banks. This result is not consistent with the existence of a "size effect" in lending, that is, that big (small) banks tend to prefer to lend to big (small) borrowers. While the reduction in interest rates is larger when the acquirer and the target banks have some market overlap (in-market) and, consequently, more potential for cost savings, the decline is much smaller when there is significant increase in local banking market concentration. That is, the change in local market concentration determines the extent to which efficiency gains 
are passed on to borrowers. From a policy perspective, this result hints at a potential concern if banking consolidation keeps up the same pace. The degree of banking concentration in some Spanish provinces is currently quite high, the majority of banks have a presence in almost all Spanish provinces, and thus there is little room for additional out-of-market mergers within Spain. One may expect that if more in-market bank mergers occur the sign of the effect of mergers on interest rates may reverse.

Even though this study only uses Spanish data and focuses on within-country mergers, some implications can be derived for the integration of the European banking market. In particular, the analysis of in-market versus out-of-market mergers can be viewed as a control environment to compare the effects of domestic mergers versus cross-country mergers where the institutional and regulatory variables are held constant.

The predictions of the effects of domestic mergers (within borders) on small businesses depend on the degree of concentration of each country banking market. In the 90s, many European countries experienced a wave of domestic M\&A. This consolidation process has clearly led to an increased banking concentration within individual European countries. Domestic consolidation was based on the conviction that a strong domestic market is necessary before moving abroad and on the policy of creating "national champions" (Group of Ten 2001). As a result, the scale and market share of banks increased within borders. In light of the results presented in the paper, one should expect only small benefits of domestic M\&A for small businesses.

After peaking in 1999, the value of European domestic banking deals has been in decline. Interestingly, since 2003 the value of European cross-border deals has been rising year after year. There are a number of reasons to believe that cross-border banking consolidation will increase in Europe during the coming years. The larger players in some countries are unlikely to grow through further domestic M\&A because their markets have become increasingly concentrated. For some time now, the European Commission has focused on the removal of impediments to European cross-border banking consolidation. The enlargement of the European Union is expected to increase the level of cross-border M\&A activity involving banks with an appetite for exposure to higher growth markets. Indeed, approximately one-third of the number of bank M\&A deals in Europe over the last ten years has involved banks in western Europe acquiring all or part of banks in emerging Europe (central and eastern Europe, the Commonwealth of Independent States, the Baltic States and Turkey) (Pricewaterhouse 2006). The results in the paper show that out-of-market mergers generate some efficiency gains, probably in terms of greater risk diversification, which are passed along to borrowers. In light of this analysis, one should expect that small businesses will benefit from increased cross-border M\&A. 


\section{Introduction}

The current trend of banking consolidation both within countries and cross-borders has raised concerns that small business may find it harder to obtain finance from increasingly large and complex financial institutions. Small and informationally opaque firms, highly dependent on banking finance to undertake their projects, would be the most directly affected. A noticeable acceleration in consolidation activity in the last decade has encouraged the proliferation of empirical studies that contribute to this debate. Most of these studies analyze banks' aggregate effects because little data on individual small borrowers is available. This paper adds to a less developed strand of the literature by analyzing the impact of bank consolidation on borrowers of merging banks by using data on bank-firm relationships in Spain. ${ }^{1}$

Bank mergers have the potential to either benefit or harm borrowers. On the one hand, mergers may generate efficiency gains - cost savings, revenue enhancing, and greater bank size can yield economies of scale and scope and increase diversification opportunities-. Borrowers will benefit to the extent that consolidated banks pass on efficiency gains to them. On the other hand, bank mergers increase market concentration. Borrowers will be harmed to the extent that consolidated banks exert their market power. In addition to this traditional merger trade-off, small business lending is characterized by the role of lenders on gathering and generating soft information about borrowers through long lasting lending relationships that help overcome informational asymmetries in credit markets. A priori, bank mergers could foster or inhibit lending relationships.

This paper analyzes the potential positive and negative effects of bank mergers to small business borrowers: Do bank mergers harm or benefit firm borrowers? In particular, the paper sheds light to the following questions: Are consolidated banks more likely to terminate their relationships with borrowers? What are the consequences of bank consolidation on interest rates? Are some particular types of borrowers more likely to be

\footnotetext{
1 Studies on the impact of bank mergers to small business using detailed bank-firm data are Sapienza (2002), Bonaccorsi di Patti and Gobbi (2005) for Italy, Degryse et al. (2006) for Belgium and Erel (2006), and Scott and Dunkelberg (2003) for the U.S..
} 
adversely affected by banking mergers? Are some particular types of mergers more likely to adversely affect SMEs?

The empirical analysis is divided into two main parts. First, I examine whether banking consolidation disrupts lending relationships. I estimate the probability of terminating existing lending relationships with merging banks and also examine whether it is harder for small businesses seeking new funding sources to establish a new lending relationship with consolidated banks. To my knowledge, this is the first paper to document initiation of lending relationships by consolidated banks. Second, I analyze the effect of banking mergers on average loan interest rates. If bank mergers create efficiency gains that are passed on to borrowers, loan rates for merging bank borrowers would decline. ${ }^{2}$ If the increase in market power outweighs merger gains, then the opposite sign would be observed.

I find several interesting results. Firms who borrow from target banks are more likely to lose their credit relationship with the consolidated bank than would otherwise identical borrowers from non-merging banks. Target borrowers are the ones who suffer the most in terms of relationship termination. I also find that borrowers seeking to start a new lending relationship have lower probability of initiating it with a consolidated bank than with other non-merging banks. That is, small businesses find it harder to get a loan from consolidated banks. These results suggest a somewhat negative effect of bank mergers to small businesses.

The second part of the analysis examines the effect of mergers on interest rates. The main result is that interest rates decrease when one of the lending banks participates in a merger. The decline in interest rates suggests that mergers are beneficial for borrowers that continue the lending relationship with the merging bank. This result supports the view that banking mergers generate efficiency gains which to some extent are passed on to small businesses.

\footnotetext{
${ }^{2}$ This is an indirect approach to measure merger gains that does not allow to distinguish between profit efficiency, cost efficiency, diversification gains, etc. In the remainder of the paper I interpret a reduction on interest rates following a merger as efficiency gains.
} 
Having identified an overall beneficial effect of bank mergers on interest rates of continuing borrowers, I focus on examining its relevance and heterogeneity through various dimensions. First, I analyze whether the effect on interest rates is temporary or permanent. One might argue that a temporary decline may just reflect, for instance, some strategic price cuts to extend the market share rather than reveal more fundamental operational improvements in the consolidated bank. I find support for a permanent reduction on interest rates, which reinforces the evidence that mergers benefit continuing borrowers.

Second, I find that the average reduction in loan spreads is larger for target borrowers than for acquirer borrowers. Since acquiring banks are usually more efficient than target banks, this result provides support for the hypothesis of efficiency gains of mergers that benefit target borrowers the most.

Third, I explore the "size effect" in lending. There is an extensive literature that explores whether small banks tend to lend to small businesses and large banks tend to lend to large businesses. If that is the case, larger banks resulting from banking consolidation may severely impact the credit availability and contract terms for small firms (Peek and Rosengren 1998, Berger et al. 1998, Strahan and Weston 1998). I find that the largest decline in interest rates corresponds to mergers involving the largest banks, which contradicts the "size effect". Interestingly, I find large drops in interest rates of borrowers of small target banks that are acquired by a large bank. This suggests that small borrowers of small banks are prime beneficiaries from transferring the lending relationship to a larger bank.

Fourth, I explore the heterogeneous effects of ownership form of merging banks. To my knowledge, this is the first paper to address this issue. Spanish banks differ on their form of ownership and governance structure. Commercial banks are shareholderoriented banks while saving banks have the ownership form of a private foundation (Crespí et al. 2004). Consistent with the property rights view, the largest reductions in interest rates are for target borrowers when two commercial banks merge.

Five, I find heterogeneous effects of bank mergers depending on the degree of market overlap. In-market mergers (involving banks that previously operated in the same 
geographical area) benefit target borrowers the most; out-of-market mergers benefit acquiring borrowers the most. Finally, I also find evidence of a market power effect. Mergers that induce a significant increase in local market concentration have a smaller impact on interest rates, reflecting the fact that consolidated banks may exploit their market power. Nevertheless, the market power effect is never large enough to offset efficiency gains.

I obtain interesting insights by dividing the sample according to the size of the borrower. I find that the smallest borrowers in the sample who are clients of target banks have a higher probability of having their lending relationship with the consolidated bank terminated and have a lower probability to initiate a new relationship with consolidated banks. I also find that the smallest and youngest borrowers in the sample that continue the lending relationship are the ones who enjoy higher interest rate declines. Taken together, these results suggest that smallest firms are disproportionally harmed by bank mergers in terms of loan supply, but those that continue the relationship benefit from having a relationship with a more efficient bank.

In sum, the results in this paper show that bank mergers have the potential to both harm and benefit SMEs. On the one had, the findings suggest a negative effect of bank mergers in terms of an increased likelihood of terminating a lending relationship for target banks. On the positive side, firms that continue the relationship with the consolidated bank experience the highest reduction on interest rate.

As stated above, the data is for Spanish firms in period 1996-2005. It is interesting to analyze this country because the relationship lending technology is widely used in Spanish credit markets, compared to other countries like the U.S.. The period analyzed is sufficiently large to capture banking consolidation due to two main reasons. First, the implantation of the Single European Market in 1992 and the culmination of the process of deregulation of the Spanish banking sector, with the special incidence of the liberalization of cross-province branching for savings banks which allowed them to open branches in any province or region since 1988. Second, the large number of mergers and acquisitions that have taken place during this period, some of them involving the largest banks, like Banco Santander and Banco Central Hispano (1999) and Banco Bilbao Vizcaya and Argentaria (1999), among many others. The analysis of 
lending relationships is particularly relevant in Spain because, like in others bank-based economies, banks are the most important providers of external finance to firms. I focus on SMEs for two reasons: first, banks are especially important for SMEs as they represent these firms' principal source of external finance, and second, because the value of relationship lending, which is based on a bank officer gathering soft information, is likely to be higher for these firms. Hence, any impact of bank mergers on SMEs may have important policy implications.

This paper contributes to the literature on banking consolidation and its effects to small businesses. Many of these papers rely on aggregate lending data from U.S. banks (Peek and Rosengren 1998, Berger et al. 1998, Strahan and Weston 1998). There is a small but growing literature that analyzes bank mergers from the small borrower perspective. Sapienza (2002) uses a loan-level data set for Italy to analyze dynamic effects of bank mergers. She finds that in-market mergers involving relatively small targets result in lower interest rates charged on loans and that mergers increase the probability of borrowers being cut off their credit lines. Erel (2006) performs a similar analysis for the U.S. and finds that interest rates decline after bank mergers. This paper is similar to Sapienza (2002) and Erel (2006) in exploring the effect of mergers on relationship termination and loan prices. One of the main contributions of this paper is the use of firm level data to control for borrower size instead of relying on loan size as a proxy. This reveals to be particularly relevant to study firm size/bank-size relation. Consistent with their findings, my results show a decline of interest rates after a bank merger. Unlike the U.S. and Italy, the decline in interest rate for small Spanish firms is observed even when large banks with market overlap merge.

Some related studies on bank mergers at the firm level are Bonaccorsi and Patti (2007) that analyze the impact of mergers on credit availability in Italy. They look at heterogeneous effects by borrower characteristics. They fail to find evidence on stronger effects for borrowers that are small, more risky and dependent on fewer lenders. Using a Belgium dataset, Degryse et al. (2006) analyze bank-firm relationships and find heterogeneous impacts of mergers. Scott and Dunkelberg (2003) use a survey of small U.S. firms in 1995 and find that banking mergers had no significant effect on availability of credit or loan contract terms to small firms. 
The paper is organized as follows. The next section briefly describes the main features of the consolidation process in the Spanish banking market in the last decade. Section 3 describes the data and the sample. Section 4 analyzes whether banking consolidation disrupts lending relationships. Section 5 examines the price effect of mergers on the continuing borrowers of the consolidated institutions. Section 6 concludes.

\section{Banking consolidation in Spain}

This paper studies the impact of bank mergers on lending relationships and loan interest rates to non-financial Spanish firms in the period 1996-2005. The period analyzed is characterized by intense merger activity involving banks of all sizes and of different ownership form. In 1996, firms in the sample had 23.5 percent of lending relationships with large banks; by the end of the sample this figure has increased to 56 percent. The Spanish banks also differ in ownership form. There are three main types of institutions: commercial banks, savings banks and credit cooperatives, which compete under equal conditions in the loan, deposit and financial service markets. Commercial and savings banks are much more important than cooperatives. Together, they account for more than $95 \%$ of the loan and deposit markets. In this paper, I focus in these two types. Commercial banks are companies owned by shareholders which hold the residual decision rights. Savings banks are not-for-profit commercial organizations whose profits are either retained or paid as a social dividend and the decision rights correspond to public authorities, depositors, workers, and the founding entity. I do not consider credit cooperatives in the analysis, which may be regarded as mutual thrifts. Additionally, official credit institutions are public entities created by the Spanish government to promote savings, economic growth, access to credit, improve wealth distribution, enhance strategic economic activities, etc. ${ }^{3}$ The particular ownership structure of savings banks implies that there is no market for corporate control for this

\footnotetext{
3 In 1872 Banco Hipotecario was created by an act of parliament to provide long-term loans for property. In 1909 Caja Postal was set up as a public entity and started operations in 1916, based on savings books. A combination of public and private interests set up Banco de Crédito Local in 1925 in the form of a joint-stock company. Its purpose was to finance local authorities and other public institutions. Banco Exterior was created in 1929 to encourage foreign trade, to seek new markets for Spanish products and to help local companies with imports and exports. Argentaria was created in 1998 as a result of the merger of Banco Exterior, Banco Hipotecario, Caja Postal and Corporación Bancaria de España.
} 
organizations and hence they cannot be acquired by commercial banks. ${ }^{4}$ During the sample period, savings banks increased significantly the number of lending relationships with SMEs from 26 percent in 1996 to 35 percent in 2005. Most notably, the number of lending relationships with large savings banks rose from zero (there are no large savings banks in 1996) to 11 percent.

I analyze all within-country mergers that occurred between 1996 to 2005. Table 1 provides the complete list of mergers, ${ }^{5}$ and table 2 provides descriptive statistics of the banks in the sample classified as target, acquired and consolidated bank. The year of the merger is that in which the consolidated bank provided unified financial statements. The classification of whether a bank is an acquirer or target is based on the classification provided by the Registry of Financial Entities. As a general rule, the acquirer is the financial institution whose entity code is passed to the consolidated bank (but there are few exceptions).

According to the Group of Ten report (2001), the most important forces encouraging consolidation are improvements in information technology, financial deregulation, globalization of financial and real markets, and increased shareholder pressure for financial performance. In Spain, starting in the mid-1980s, regulations such as interest rate controls, branching restrictions, solvency and investment requirements, accounting rules and entry constraints were relaxed. This lead to a branching expansion strategy through mergers with banks operating in different provinces. In the report, Spanish bankers affirm that banking mergers are needed to face the upcoming European consolidation that is expected to take place. In light of these arguments, it seems reasonable to assume that Spanish banking consolidation was mainly driven by deregulation and a policy of creating "national champions" to expand scale and market share (Carbó et al. 2007). Finally, it is important to mention that the completion of mergers of existing banks is subject to authorization by the Spanish Minister of

\footnotetext{
${ }^{4}$ See Crespí et al. (2004) for a comprehensive discussion on governance mechanisms in Spanish banks.

${ }^{5}$ The merger between Activobank and Banco de Sabadell is included in the merger list for completeness, however, none of the firms in our sample borrows from Activobank, and hence, no analysis can be done with respect to that merger at the borrower level (Activobank was operating in Spain during three years from 2000 to 2002, with only one and two branches).
} 
Economy, on the basis of an opinion from the Bank of Spain (national supervisory authority). ${ }^{6}$

\section{Data}

I use three sources of data. The primary source of firm-level information is the SABI (Sistema de Análisis de Balances Ibéricos) database by Bureau Van Dijk. This database includes accounting and financial information for more than 600,000 Spanish firms for the period 1990 to 2005 that was obtained from the annual financial statements deposited at the Registry of Companies. The number of firms included in the database has been increasing with time as a result of increased effort to compile a comprehensive database. To be included in the database the firm must have at least one employee. Even though it is not a stratified sample, the included firms are representative of the whole population of Spanish firms. Apart from accounting data, there is also some complementary information about the firms, like headquarters location, date of constitution, firm industry, number of employees, legal form of the business, the opinion of the auditor, whether the firm quotes in the stock exchange and the name of the banks with whom the firm usually operates. ${ }^{7}$

The SABI database is updated regularly. The historical series are not available for some variables, such as the names of the lenders (only the current observation of the variable is kept in the database). In order to have a complete panel dataset on the lending relationships I recoded this variable from previous updates of the database, one per year, from 1998 to 2007 . With this procedure, I recovered information on the firm lenders from 1996 to 2005, which determines the period of analysis. Firms that report lending relationships with two branches of the same bank are considered as having one lending relationship with that financial institution. The identity of the banks lending to these firms is matched with data on bank merger activity from the Bank of Spain Registry of Financial Entities (Renbe). This database keeps record of relevant events that entail a

\footnotetext{
${ }^{6}$ Banco de España, 2001, "Basic Regulatory Structure of the Spanish Banking System”, Annex I to Annual Report.

${ }^{7}$ The variable "name of banks" is crucial for the analysis. Unfortunately, the only available information is the name of the banks with whom the firm usually operates with no other details. In particular, it does not allow to identify lending banks from banks providing other type of financial services. A firm is defined to have a lending relationship with a lender when a firm reports the name of a bank in this variable.
} 
change on the entity code assigned by the Bank of Spain to any financial firm that operates in Spain, like new registered financial firms, banks that terminate operation, and to our interest, all mergers and acquisitions involving financial firms. By matching the information on the identity of the lenders from the SABI database with the bank mergers dates from the Registry of Financial Entities, I can identify the borrowers of merging banks. This information would be crucial to examine the impact of the merging activity of lending banks to its borrowers.

The bank level data is obtained from the publicly available financial statements contained in the Annual Statistics of the Spanish Banking Association (AEB) and the Annual Statistics of the Spanish Savings Banks Confederation (CECA). From these data sources we obtain financial statements of commercial and savings banks respectively, as well as information on the number of bank branches for each financial institution by province and year.

\subsection{Sample}

From the SABE database I select firms not listed in the stock exchange, with information on bank relationships, in all industrial sectors except finance, insurance and public firms ${ }^{8}$ that during the period of analysis (1996-2005) complied with the SME condition according to the requirements established by the European Commission recommendation 2003/361/EC on the definition of small and medium-sized firms. Specifically, the sample of firms is made up of enterprises which employ fewer than 250 persons and which have an annual turnover not exceeding $€ 50$ million, and/or an annual balance sheet total not exceeding $€ 43$ million. Within the SME category, a small enterprise is defined as an enterprise which employs fewer than 50 persons and whose annual turnover and/or annual balance sheet total does not exceed $€ 10$ million. A micro enterprise is defined as an enterprise which employs fewer than 10 persons and whose annual turnover and/or annual balance sheet total does not exceed $€ 2$ million. Firms need to have at least two consecutive observations to be included in the sample. If both

\footnotetext{
${ }^{8}$ In particular, we drop firms in the following industry sectors: Depository Institutions, Non-depository Credit Institutions, Security and Commodity Brokers, Dealers, Exchanges, and Services, Insurance Carriers, Insurance Agents, Brokers, and Service, and Public Administration (SIC codes 60 to 64 and 90 to 99$)$.
} 
consolidated and non consolidated accounts are available, the non consolidated ones are used. All nominal values have been converted to real values by deflating by the consumer price index $(2000=100)$.

The final sample consists of an unbalanced panel of firms in the period 1996-2005, ${ }^{9}$ with a total of 674,735 firm-year observations corresponding to 124,213 firms. The average number of observations per firm is 5.5, ranging from a maximum of 10 observations for about 40 percent of the firms in the sample and just one observation (with lagged values) for 4 percent of the sample. The maximum number of firms is achieved in year 2005 with 90,734 observations in the sample, which represents 6.23 percent of the total population of Spanish SME with at least one employee in that year. Table 3 provides descriptive statistics of some variables for the firms in the sample.

In the analysis presented in section 4 the unit of analysis is a bank-firm relationship. The sample is comprised by 1,351,069 bank-firm-year observations corresponding to 300,225 bank-firm relationships.

The analysis on price effects of mergers in section 5 is conducted at the firm level. The dependent variable is the average interest rate that firms pay for external finance (Interest rate). For a given firm and year, the average interest rate is calculated by dividing the financial expenses at the end of the year by the average amount of debt held during that year (debt at the beginning of the year plus debt at the end of the year divided by two). This computation generates some extreme values in the average interest rate for some observations. Therefore, the variable is winsorized at the 99.5 percentile, which corresponds to an interest rate of 23.88 percentage points (this procedure affects 3,061 firm-year observations).

The data provides information on the name of the lenders, but there is no disaggregated information at the loan level. Although this data limitation prevents to measure the effect on interest rates of those loan granted by merging banks, it has the advantage that I can measure the impact on the average interest rate paid in subsequent periods even when the lending relationships is terminated. Existing research in Italy (Sapienza 2002),

\footnotetext{
${ }^{9}$ Information corresponding to 1995 is also used to construct lagged variables of firm and bank characteristics.
} 
the U.S. (Erel 2005) and Belgium (Degryse et al. 2005) evidences higher discontinuation rates for target borrowers. My results in section 5 are consistent with this finding. The advantage of this dataset is that I can analyze the average interest rate that a firm pays even when the relationship is terminated.

\subsection{Definition of relevant market}

The next issue we need to address is the choice of relevant market where banks compete for clients. It is sensible to assume that competition among banks takes place at a regional level because usually small firms only operate at a local level and seek banking finance close to their location. Additionally, some research in other countries shows that the distance between the firm and its lenders is very low and it has not increased significantly with the implantation of the new information technologies. Therefore, I define the province where the firm is located as the relevant market where banks compete for borrowers, as in previous Spanish studies (e.g. Maudos 1998). Firms that have lending relationships with banks outside the province (relevant market) represent $1.5 \%$ of the bank-firm-year observations $(20,285$ out of $1,351,069)$.

\section{The effect of bank mergers on termination and initiation of lending relationships}

The primary source of small business finance are banks, and usually, small firms tend to concentrate their borrowing at a single or few banks. Bank mergers may adversely affect small business if consolidating banks are more likely to terminate ongoing lending relationships with existing borrowers. Furthermore, banking consolidation can make it more difficult for small business seeking new financing sources to start a lending relationship with a newly consolidated financial institution. In this section I examine whether this is the case. For the first hypothesis, I estimate a probit model on the probability of terminating a relationship as a function of lenders' merger activity. For the second hypothesis, I estimate a probit model for the probability of initiating a relationship as a function of lenders' recent merger activity.

The specifications of the models are the following: 
$\operatorname{Pr}\left(\right.$ terminate relationship $\left._{i k t}\right)=F\left(\right.$ Target $_{\text {borrower }}$ ikt, Acquirer borrower bikt $_{\text {, Firm }}$ controls $_{i k t}$ Lender characteristics $s_{i k t}$, Time dummies, Province dummies, $\left.\varepsilon_{i t}\right)$

$\operatorname{Pr}\left(\right.$ initiate relationship $\left._{i k t}\right)=F\left(\right.$ Consolidated borrower $_{i k t}$, Firm controls $s_{i k t}$, Lender
characteristics $_{i k t}$, Time dummies, Province dummies, $\left.\varepsilon_{i t}\right)$

where each observation represents a bank-firm relationship at time $t$. In the first model, the dependent variable Terminate relationship ${ }_{i k t}$ equals one in year $t$ if firm $i$ does not report having a relationship with bank $k$ in year $t+1$. In the second model, the dependent variable Initiate relationship $p_{i k t}$ equals one in year $t$ if firm $i$ did not report having a relationship with bank $k$ in year $t-1$. The explanatory variables that proxy for merging activity are the following. In the first model, the variable Target borrower ${ }_{i k t}$ equals one if bank $k$ is a target bank in a merger occurring between $t$ and $t+1$. The variable Acquirer borrower $_{i k t}$ equals one if bank $k$ is an acquirer bank in a merger occurring between $t$ and $t+1$. In the second model, the variable Consolidated borrower ikt $_{\text {equals }}$ one if bank $k$ is a consolidated bank resulting from a merger occurred between $t-1$ and $t$. Both models include a set of firm characteristics and lender characteristics. All regressions include year dummies and province dummies. $\varepsilon_{i t}$ is assumed to be a zero mean, randomly distributed error term. All reported coefficients are the marginal effects on the probability of discontinuing the lending relationship evaluated at the sample mean of the explanatory variables.

Firm characteristics measured at $t-1$ are included in the model. The logarithm of total assets (Log firm assets) and of sales (Log firm sales) as measures of firm size. Some financial ratios: proportion of current assets over current liabilities (Liquidity), ratio of fixed assets over liabilities to control for the tangibility of its assets (Collateral), EBIT over assets to measure firm profitability (Firm ROA) and firm liabilities scaled by total assets (Leverage). I additionally include the Altman Z-score as independent variable in the regression to capture the firm credit risk. ${ }^{10}$ This is a compound measure built from

${ }^{10}$ The Altman Z-score is calculated as: $\mathrm{Z}=0.012$ [working capital/assets] +0.014 [retained earnings/assets] +0.033 [EBIT/assets] +0.006 [equity/liabilities] +1 [sales/assets]. Although in the 
accounting ratios that helps to predict how close a firm is to bankruptcy (Altman 1968). A higher Z-score implies a lower default risk. I use the logarithm of age (Log firm age) to capture the effect of firm life cycle. The Number of lenders at $t-1$ is also included in the regression to control for the differential effects of firms with multiple relationships compared to firms with only one lending relationship.

As for lender characteristics, I include bank size (Log lender assets) and bank profitability (Lender ROA). I also include dummies for bank size. ${ }^{11}$ Finally, HerfindahlHirschman Index $(H H I)$ of bank branches by province and year is included in the regression as a measure of banking market concentration. ${ }^{12}$

\subsection{Termination of lending relationships}

The sample consists of 1,351,069 bank-firm-year observations that correspond to 300,225 bank-firm lending relationships. 3.78 percent of lending relationships are terminated during the sample period. The variable Target borrower equals one in 28,431 observations; 7 percent of these relationships are terminated. The variable Acquirer borrower equals one for 140,438 observations and only 3.24 percent of these relationships are terminated. The descriptive evidence suggests a higher discontinuation rate for target borrowers. In order to check whether the results hold once we control for observable firm and lender characteristics I estimate model (1). The results can be found in panel $\mathrm{A}$ of table 4 , column $1 .^{13}$ Target borrowers have a higher probability of terminating a relationship $(+1.8$ percentage points $)$ while acquiring borrowers have a lower probability of terminating the relationship (-0.7 percentage points). Existing studies also find a higher discontinuation rate for target borrowers than for acquirer

original model the fourth ratio is calculated by market value of capital / book value of debt, here we have used the alternative proposed by Scherr and Hulburt (2001): the book value (and not the market value) of equity. This is because the market value is not available in the case of SMEs.

${ }^{11}$ Following Delgado et al. (2007), banks are grouped into three size classes: small (€1000 million in total loans or less), medium (between $€ 1000$ and 25,000 million) and large (above $€ 25,000$ million).

12 The HHI is a market concentration measure computed as the sum of the squares of each bank's market share for all banks in a market. The number of branches that each bank has in each province by year is used to compute the HHI because no information currently exists concerning the regional distribution of the representative variables of banking output (deposits, loans). Only regional branch distribution data are available. Therefore, market shares are calculated using regional branch distribution data which proxies for deposit distribution.

${ }^{13}$ The number of observations in the regressions is reduced to $1,142,521$ due to missing values in some explanatory variables. 
borrowers (Sapienza 2002, Degryse et al. 2005). This finding suggests that target borrowers are the most hurt by banking consolidation.

So far, I interpreted a discontinuation of a lending relationship as being a bank's choice and being harmful from the borrower point of view. The reason for that interpretation is that the literature on lending relationships establishes that longer and stronger bank-firm relationships are value enhancing as it is reflected on a higher probability of obtaining a loan (Cole 1998), lower loan rates (Petersen and Rajan 1994, D’Auria et al. 1999), and lower collateral requirements (Berger and Udell 1995, Harhoff and Körting 1998). In light of these findings one would expect that continuing the lending relationship should be optimal from the borrower point of view. Moreover, in the next section I examine the effect of relationship termination and switching behavior on interest rates. The results show that continuing borrowers are the ones that benefit more from banking consolidation, which reinforces the interpretation that borrowers would prefer to continue the lending relationship if allowed to do so.

However, as Korceski et al. (2006) argue, this might not always the case. When switching costs vary across different types of customers it is not obvious whether the welfare effect of continue/terminate a relationship with a consolidated bank is, on balance, positive or negative. On the one hand, firms with high switching costs do not terminate the relationship because they are locked in the relationship and find it difficult to start new lending relationships because of adverse selection problems in credit markets (Sharpe 1990, Rajan 1992). If that is the case, continue the relationship would be harmful from the borrower point of view. On the other hand, firms with low switching costs may find it profitable to drop the consolidated bank and start new lending relationships. It may even be the case that they do not need to start a new relationship and they just need to switch the funding amount from the merging bank to previously existing relationships. If this is the case, borrowers terminating the relationship with the merging bank will be better off. In this context, the coefficients in table 4 have no obvious interpretation. The higher probability of terminating a relationship for target borrowers may reflect the fact that target banks are generally weak and badly managed banks and thus they are also more likely to lose customers. ${ }^{14}$

\footnotetext{
${ }^{14} \mathrm{I}$ am indebted to an anonymous referee for pointing out this caveat and suggesting how to address it.
} 
In that sense, the discontinuation of a lending relationship may reflect a borrower's choice instead of a bank decision.

In order to disentangle this competing interpretations, I divide the sample of firms into low and high quality borrowers using several observed characteristics. In the scenario of a weak target bank, one would expect that all types of firms (low and high quality) will decide to terminate the lending relationship with the target bank. On the contrary, if banks take the decision to terminate the lending relationship, one should observe banks severing relationships with low quality firms. I estimate model (1) with the variables Target borrower and Acquirer borrower interacted with three dummy variables (D1, $D 2, D 3)$ that proxy for firm quality: size, age and z-score.

The results can be found in columns 2 to 4 in panel A, table 4 . The regressions show that target borrowers have a higher probability of terminating a relationship while acquiring borrowers have a lower probability of terminating the relationship. The last two rows test the equality of the coefficients Target $* D 1$ and Target $* D 3$. For size and age the null hypothesis is rejected, which shows that smaller and younger firms are more likely to terminate a relationship with a target bank. This result is consistent with Degryse et al. (2006). When firms are divided according to the z-score (column 4) the difference is no longer significant at 5\%. Taken together the results support the hypothesis that the most informationally opaque firms are the ones that are more hurt by lending relationship discontinuation as a consequence of mergers. It seems plausible to assume that banks are generally the ones who terminate lending relationships with small businesses.

The regression controls for firm characteristics. Larger, older, more levered, more profitable and firms with more lenders have a higher probability that the lending relationship is terminated. More liquid and less risky, as measured by the Z-score, have a lower probability. The regression also controls for bank characteristics. The most significant effect is for bank profitability. More profitable lenders are much less likely to terminate the lending relationship than unprofitable ones. This coefficient is basically 
capturing bank bankruptcy. Larger banks are less likely to terminate lending relationships than their smaller counterparts. ${ }^{15}$

\subsection{Initiation of lending relationships}

During the sample period, firms establish 69,975 new bank-firm lending relationships. 9.48 percent correspond to new lending relationships with a consolidated bank in the year of the merger. In this section I estimate initiation rates for consolidated banks and non-consolidated banks in order to test whether banking mergers make it harder for small businesses seeking new funding sources to establish a new lending relationship with consolidated banks. I empirically examine whether this is the case by estimating model (2). The results can be found in panel B of table 4, column 5. I find a lower probability of initiating a new relationship with a consolidated bank than with other banks ( -0.8 percentage points). In column 6 to 8 I estimate the model with the variable Consolidated borrower interacted with three dummy variables depending on borrower size, age and z-score, respectively. I find an even smaller initiation rate of new relationships with consolidated banks for the smallest and youngest firms in the sample. Once more, the results support the hypothesis that the most opaque firms are more negatively affected by bank mergers.

\section{The effect of bank mergers on average interest rates}

In this section I examine how the average interest rate on business debt changes due to lenders' merger activity, controlling for several firm characteristics, lenders' characteristics and local credit market controls. I start by estimating a basic model to measure the overall impact of bank mergers on loan rates, and then, I analyze differential effects by various dimensions: target and acquirer borrowers, characteristics of the borrowers, characteristics of banks involved in mergers, and different market structures.

\footnotetext{
${ }^{15}$ Some robustness checks have been performed by including sector fixed effects, bank fixed effects, and adding some explanatory variables like length of bank firm relationship and measures of bank competition. Overall, the results are similar to the baseline regression.
} 
5.1. The basic model and definition of variables

To examine the effect of mergers on the average interest rate that a firm pays on its debt, I estimate the following model:

$$
\begin{aligned}
& {\text { Interest } \text { Rate }_{i t}=\alpha+\beta \text { Merger }+\gamma \text { Firm characteristics }}_{t-1} \\
& +\theta \text { Lenders characteristics }_{t-1}+\varphi \text { Credit market controls }_{t-1} \\
& +d_{t}+f_{i}+\varepsilon_{i t}
\end{aligned}
$$

where the dependent variable, Interest Rate $_{i}$, is the average interest rate charged at time $t$ by the lenders of firm $i$. I estimate several specifications of the above general model by using various variables to account for the effect of mergers. The model includes a set of firm characteristics, lender characteristics and some local market controls. All regressions include time dummies $d_{t}$ and firm fixed effects $f_{i}$ that capture unobserved firm heterogeneity. $\varepsilon_{i t}$ is assumed to be a zero mean, randomly distributed error term. The standard errors are clustered at the regional (province) level .

Data on observable firm characteristics measured at $t-1$ are used to reduce the impact of heterogeneity of firms in our sample. Firm and credit market variables are the same as in section 4. The rationale for including them is the following. The logarithm of total assets (Log firm assets) and of sales (Log firm sales) as measures of firm size. Larger firms are usually more informationally transparent and this may impact loan interest rates. A firm's cost of credit may depend upon the liquidity and the tangibility of its assets. The former is proxied by the proportion of current assets over current liabilities (Liquidity) and the later by the proportion of fixed assets over liabilities (Collateral) which controls for the firm capability to pledge collateral. I use the logarithm of age (Log firm age) to capture the effect of firm life cycle and the fact that firms become more informationally transparent with age. The Number of lenders at $t-1$ is also included in the regression. I also include additional financial characteristics and balance sheet indicators of the firm because the banks usually take them into account when screening and monitoring the firm to make credit risk analysis. The ratios included are 
measures of firm profitability (Firm ROA) and firm liabilities scaled by total assets (Leverage). I additionally include the Altman Z-score as independent variable in the regression to capture the firm credit risk as defined in section 4 .

Bank variables are re-defined because the level of observation is a firm that may borrow from several banks. So, lender characteristics are the average of the variables over all lenders by firm at time t. The variables are bank size (Average assets of lenders) and bank profitability as measured by the ratio of return before taxes over assets (Average ROA of lenders). Finally, Herfindahl-Hirschman Index (HHI) is included in the regression as a measure of banking market concentration in the province.

\subsection{Main results}

Table 5 shows the results of the estimation of equation (1) under various specifications for the MERGER variable. As in Sapienza (2002) I start by estimating the impact of mergers for continuing borrowers, that is, firms that borrow from the target and/or the acquiring bank the year before the merger and borrow from the consolidated bank the year after the merger. Later on in section 5.6 I distinguish between firms that continue the relationship with the merging bank and those that do not. The first model estimates the one-period static impact of bank mergers on borrowers interest rates. I use a dummy variable MERGER(t) that is equal to one if one or more of the firm lenders are involved in M\&As in a given year $t$, and zero otherwise ${ }^{16}$. The coefficient measures the temporary impact of a merger on interest rates. Since the model includes firm fixed effects, a positive (negative) value of the coefficient means that the average interest rate of a firm affected by a merger is larger (smaller) in the year of the merger than the average interest rate for that firm over all the other periods in which none of its lenders participates in M\&A. The results in table 5 column 1 show that the average interest rate drops by 4.9 basis points. This suggests that when lenders are involved in merger activity its borrowers enjoy significantly lower interest rates in the year of the merger.

\footnotetext{
${ }^{16}$ For example, Banco Santander and Banco Central Hispano Americano merged in January 1999 and become BSCH as consolidated bank. Then, MERGER ( $\mathrm{t}=1999)$ equal one for firms that borrow from any of the two institutions in 1998 and from BSCH in 1999.
} 
This supports the efficiency hypothesis that banks pass on borrowers some of the benefits generated in bank mergers.

As far as the characteristics of the firm are concerned, size (measured by firm assets) displays the negative expected sign. Larger firms obtain cheaper external finance. Firms more indebted and with higher growth opportunities (measured by firm sales) have higher cost of capital. Age has a positive effect on cost of capital. Profitability, liquidity and the availability of collateral have a positive effect on cost of capital. Surprisingly, the Z-score variable that controls for firm creditworthiness has a positive sign; it does not confirm Rajan's (1992) theoretical prediction that firms with a higher probability of failure should suffer more from informational hold-up problems. The larger the number of lenders the larger the average interest rate on loans.

The regression also controls for bank characteristics. The most significant effect is for bank profitability. I find that larger and more profitable lenders charge lower interest rates on loans. Finally, the coefficient for HHI is positive but non-significant, showing that greater banking market concentration tends to increase interest rates but the relationship is not strong.

\subsection{Temporary and permanent effects}

Although the estimated coefficient for the MERGER(t) variable in this model is significant, this specification only accounts for a temporary reduction of interest rates in the year of the merger. In order to test whether the effect on interest rates is permanent, I use a dummy variable $\operatorname{MERGER}(\mathrm{t}, \mathrm{T})$ equal one in all years after one of the firm lenders is involved in M\&As, and zero otherwise ${ }^{17}$. If there is more than one lender involved in M\&A, this variable takes value one after the first merger in the sample period. Since the model includes firm fixed effects, this specification compares the average interest rate of a firm before and after one of its lenders participates in M\&A. The results in column 2 show that the average interest rate is 10.6 basis points lower in subsequent years after a bank merger.

\footnotetext{
${ }^{17}$ Following the previous example, MERGER (t,T) equal one from 1999 to 2005 for firms that borrow from any of the two institutions in 1998 and from BSCH in 1999.
} 
To further disentangle the temporary and permanent effects, I estimate a model with the dummy variable MERGER(t) and a new dummy variable MERGER(t+1,T) that is equal to one in all years after one of the firm's lenders is involved in M\&As except for the year of the merger itself. If the firm's lenders are involved in M\&A in different years, this variable equals zero for all the years that a merger occurs. In this specification, MERGER( $(t)$ captures the short run effect and MERGER $(t+1, T)$ captures the long run effect of bank mergers on interest rates. The results reported in column 3 show that there are significant short run and long run effects of mergers on interest rates of -10.9 and -9.7 basis points respectively (the average interest rate is 3.50 percent). However, the difference between the short run and long run effect is not statistically different from zero $\left(\mathrm{F}_{(1,51)}=1.49\right.$, $\mathrm{p}$-value $\left.=0.2284\right)$. Therefore, the preferred specification is column 2 . This suggests that the reduction in interest rates is permanent.

In sum, the main result presented in this section is that interest rates decline after a bank merger, which is consistent with the efficiency hypothesis. The following sections focus on estimating the heterogeneous effects of mergers on borrowers of acquirer and target bank, overlap borrowers, and firms terminating the lending relationship with the consolidated bank.

\subsection{Target versus acquirer borrowers}

Most studies find that prior to the merger targets perform poorly compared to acquirers (Amel et al. 2004). The descriptive evidence provided in table 2 also points in that direction. Therefore, efficiency gains are expected to be larger for target banks than for acquirers. A main contribution of this paper is to estimate differential effects between target and acquirer borrowers. If the main motivation for banks to merge is to increase efficiency (for instance, by replacing poorly performing target bank management), one should expect larger interest rate cuts for the target borrowers than for the acquirer borrowers. To test this hypothesis we define a dummy variable TARGET(t,T) that is equal to one in all years after one of the firm lenders is a target bank in a merger, and zero otherwise. ACQUIRER( $(\mathrm{t}, \mathrm{T})$ is defined analogously for borrowers of acquirer banks. In the case that a firm borrows from a target and an acquirer (for the same or a 
different merger), then both variables are equal to one. The results are reported in column 4 of table 5. As expected, borrowers from target banks experience a larger reduction on interest rates (19.8 basis points) than borrowers of acquiring banks ( 9 basis points), the difference being statistically significant different from zero $\left(\mathrm{F}_{(1,51)}=7.27, \mathrm{p}\right.$ value $=0.0095$ ). This suggests that target borrowers are the ones who benefit the most from bank mergers. ${ }^{18}$

The next specification accounts for differential short and long run effects for target and acquirer borrowers. The results in column 5 show that borrowers of target (acquirer) banks experience a reduction of interest rates of 14.6 (9.2) basis points in the short run and of 22.4 (8.2) basis points in the long run. For acquirer borrowers, the short and long run effects are statistically equal $\left(\mathrm{F}_{(1,51)}=0.96\right.$, $\mathrm{p}$-value $\left.=0.3326\right)$. Interestingly, for target borrowers the long run effect is larger than the short run effect $\left(\mathrm{F}_{(1,51)}=14.15\right.$, $\mathrm{p}$ value $=0.0004)$. That is, borrowers of the usually more inefficient target bank obtain some efficiency gains in the short run and are further benefited from the bank merger by having access to a more efficient and larger bank because of the merger. This evidence is consistent with the fact that some time is needed for the restructuring process after a merger, so that the benefits of mergers are fully passed on to target borrowers one year after the merger. Sapienza (2002) finds that for Italian consolidated banks it takes about four to six months to revise loan interest rates.

So far, I interpreted the reduction on interest rates as merger efficiency gains. An alternative explanation for this finding is that continuing target borrowers have higher quality than acquiring borrowers. The consolidated bank reduces interest rates to the highest quality borrowers when the new borrower pool is added in its portfolio. This hypothesis may seem plausible in light of the results presented in the first part of the analysis. Smaller and younger borrowers of target banks are more likely to terminate their relationship with the target bank than large borrowers. The larger interest rate drop

\footnotetext{
${ }^{18}$ The model is re-estimated by restricting the sample to firms that experience just one merger event during the sample period plus a control group of firms that are not affected by any merger. Although one may introduce sample selection by applying this criteria (for instance, smaller firms are likely to experience a smaller number of mergers due to their restricted scope on the number of lenders), the model is estimated with this restricted sample to avoid composition of effects. That is, the identification of effects due to the current merger with respect to the lagged effects of a previous merger are blurred. In this subsample the variables TARGET(t,T) and ACQUIRER(t,T) are never simultaneously equal to one. Although the number of observations is reduced by sixty percent, the results are qualitatively similar (target: -20.4 basis points, acquirer -5.8 basis points).
} 
for continuing target borrowers may be driven by a selection bias in which acquiring banks simply identify good borrowers of poorly performing target banks. In section 5.10 I show that the results remain qualitatively the same once we control for selection.

\subsection{Overlap borrowers}

There is a particularly interesting group of firms that have a lending relationship with both the target and the acquiring bank before a merger and continue the lending relationship with the consolidated bank after that merger. These "overlap" borrowers drop one lending relationship as a consequence of the merger. In this section I explore the effect of bank mergers for "overlap" borrowers. On the one hand, one should expect that overlap borrowers would be adversely affected by mergers because of the loss of one lending relationship which may imply a loss of bank-firm specific information and a reduction of bargaining power vis-à-vis lenders. This effect should be particularly important for firms facing high switching costs. On the other hand, overlap borrowers receive efficiency gains generated by the merger and may benefit from the combination of information of the two lending institutions into one.

To examine the differential effects for overlap mergers, I define a new dummy variable $\operatorname{OVERLAP}(\mathrm{t}, \mathrm{T})$ equal to one in all years after a firm borrows from both target and acquirer in a given merger. Additionally, the variables TARGET $(\mathrm{t}, \mathrm{T})$ and ACQUIRER(t,T) are re-defined to be equal to one in all years after one of the firm's lenders is a target (acquirer) bank in a merger and no other lender is the acquirer (target) for that merger, and zero otherwise. The results are presented in column 6. Overlap borrowers experience the highest reduction in interest rates (22.3 basis points), compared to 17.9 of target borrowers and 8.0 of acquirer borrowers. This result would suggest that overlap borrowers are not harmed by the loss of one lending relationship. The difference between overlap and target borrowers is not statistically different from zero $\left(\mathrm{F}_{(1,51)}=1.10, \mathrm{p}\right.$-value $\left.=0.3002\right)$, suggesting that the effect of mergers for overlap borrowers is similar to that of target borrowers. This finding is consistent with the results obtained by Bonaccorsi and Patti (2007) of no significant change on credit availability for overlap borrowers compared to target borrowers. 
I estimate the model with a restricted sample by eliminating those firms that initiate a new lending relationship with a consolidated bank in the year of the merger (column 7 , table 5). ${ }^{19}$ Excluding new borrowers controls for potential biases due to changes in the composition of the pool of firms borrowing from the consolidating bank. The estimated results show that the average reduction in interest rate is even larger for all firms: target, acquirer and overlap borrowers.

\subsection{Continuing, terminating and switching lending relationships}

When a lending bank participates in a merger, its borrowers face a change in their funding sources and are subject to the new lending policy of the consolidated bank. As a consequence, lending relationships with the consolidated bank may continue or may be terminated, and new lending relationships may be initiated. These changes in lending relationships may reflect either a bank's decision or a firm's choice. In the analysis on interest rates presented so far, I considered the impact of mergers to continuing borrowers, that is, firms that borrow from the target and/or the acquiring bank the year before the merger and borrow from the consolidated bank the year after the merger. In this section I estimate differential effects for continuing borrowers and those that terminate the relationship with the consolidated bank in the year of the merger. Following Degryse et al. (2006), I also differentiate between relationship discontinuations that are simultaneously replaced by a new lending relationship started in that same year (switch) from pure relationship discontinuations, that is, firms that terminate the relationship with the merging bank and do not add new lending relationships (no switch). The distinction between firms that switch banks and firms that do not is particularly relevant for overlap borrowers because they experience a drop of one lending relationship as a result of the merger. It is expected that overlap borrowers would be more inclined to establish a new lending relationship following a merger than borrowers of only one merging bank.

Before looking at the results, it is important to highlight that decisions regarding lending relationships are made simultaneously with the determination of loan terms. For

\footnotetext{
${ }^{19}$ The number of firms dropped is 12,010 and the number of firms included in the regression is 112,203.
} 
instance, consider a target borrower that would experience an increase in interest rate when renewing the loan with the new consolidated bank. Instead of accepting unfavorable loan rates in the consolidated bank, it may seek funding at better terms from an existing relationship or switch to a new bank. In that case, borrowers that discontinue the relationship would pay lower interest rates than continuing borrowers. That is, the average interest rate that the firm pays would be endogenously determined with the termination and switching decision. The results in this section should be interpreted with this limitation in mind.

For comparability of results, in the first column of table 6 I reproduce the results of the model that estimates differential effects for overlap, target, and acquirer continuing borrowers. In column 2 I estimate a model with differential effects for target, acquirer and overlap borrowers that continue or terminate the relationship with the consolidated bank $^{20}$. The variable "Target \& Terminate" is a dummy variable equal one in all years after a firm that borrows from a target borrower terminates the relationship with the consolidated bank. The remaining variables are defined accordingly. The coefficients for continuing firms are fairly similar to those in column 1. Controlling for borrowers that terminate the relationship does not alter the sign or the magnitude of the main results. For discontinuing borrowers, the impact on interest rates is much smaller and only the coefficient for target banks is significantly different from zero. These results reinforce the interpretation of efficiency gains in mergers that are passed on to continuing borrowers. Firms that discontinue the lending relationship with the consolidated bank pay interest rates similar to non-merging banks borrowers. The significant reduction of interest rates for target borrowers that terminate the lending relationship is consistent with the interpretation that target banks are usually more inefficient and hence the loss of this lending relationship indeed benefits its borrowers. In order to further check the significance of this result, in the third column I estimate the same model by eliminating from the sample firms that initiate a new lending relationship with a consolidated bank in the year of the merger. As explained before, the inclusion of new borrowers of consolidated banks may bias the results because, for instance, the new consolidated bank may follow a lending policy of flight to quality. The estimated results show that the effect on interest rates for continuing borrowers is

\footnotetext{
${ }^{20}$ Overlap borrowers that terminate the relationship with the consolidated bank experience a drop of two lending relationships.
} 
now stronger while for discontinuing borrowers it is not significantly different from zero, even for target borrowers.

Next, I estimate differential effects for discontinuing borrowers depending on whether they start a new lending relationship or not. The results can be found in column 4 . The variable "Target \& Terminate \& Switch" is a dummy variable equal one in all years after a firm is a target borrower, terminates the relationship with the consolidated bank and starts a new lending relationship in the year of the merger. The coefficients for continuing firms are fairly similar to those obtained so far. For discontinuing borrowers, the only significant coefficient is for "Target \& Terminate \& No Switch" borrowers. This result is consistent with the fact that firms with high switching costs that are dropped from the consolidated bank may prefer to increase the borrowed amount from previously existing lending relationships instead of starting a new lending relationship. I cannot test whether this is indeed the case because of lack of disaggregated data on amount borrowed from each lender. Nevertheless, the reduction of interest rates for these borrowers is smaller than the reduction enjoyed by target continuing borrowers. The results show that terminating the lending relationship with the consolidated bank prevents firms from receiving benefits of more efficient consolidated banks. Assuming firms choose their lenders optimally, this finding indicates that termination of relationships is most likely a bank's decision. Otherwise, firms would choose to borrow from more efficient banks granting lower interest rate loans. As before, I estimate the same model by eliminating from the sample firms that initiate a new lending relationship with a consolidated bank in the year of the merger. The estimated results in column 5 show that the effect on interest rates for continuing borrowers is somewhat stronger while for discontinuing borrowers it is not significantly different from zero.

The distinction between firms that switch banks and firms that do not is particularly relevant for overlap borrowers because they experience an exogenous reduction of one lending relationship as a result of the merger. It is expected that overlap borrowers would be more inclined to establish a new lending relationship following a merger than borrowers of only one merging bank. In column 6, overlap continuing borrowers are separated into two groups. "Overlap \& Continue \& Switch" is a dummy variable equal one in all years after a firm is an overlap borrower, continues the relationship with the consolidated bank and starts a new lending relationship in the year of the merger. 
“Overlap \& Continue \& No Switch" is a dummy variable equal one in all years after a firm is an overlap borrower, continues the relationship with the consolidated bank and does not starts any lending relationships in the year of the merger. This specification tests for the importance for overlap borrowers to replace the lost lending relationship. The coefficients estimated show that overlap borrowers experience a reduction in interest rates regardless of whether they are able to replace the lost lending relationship or not. We cannot reject the null of equality of coefficients $\left(F_{(1,51)}=0.01\right.$, pvalue $=0.941$ ). In the last column I estimate the model by including dummies of relationship termination and further dividing overlap borrowers that terminate the lending relationship with the consolidated bank between switching and non-switching firms. The estimated results are consistent with those discussed above.

In sum, the results presented so far show that interest rates decline after a bank merger, which is consistent with the efficiency hypothesis. The decline is permanent and larger for acquirer borrowers. Overlap borrowers show effects similar to target borrowers. Firms terminating the relationship with the consolidated bank have effects similar to non-merging bank borrowers, and hence are included in the control group. In the remainder of the paper, I report the models corresponding to permanent effects using the variables TARGET(t,T) and ACQUIRER(t,T). The regressions with temporary effects, overlap borrowers, and dummies for terminating borrowers are always estimated; the results are discussed only when they differ from those reported in tables. The following sections focus on estimating the heterogeneous impact of mergers by borrower's characteristics and type of merger.

\subsection{Borrower size and age}

The impact of mergers can be stronger for firms facing more acute informational asymmetries and high switching costs. In this section I investigate whether bank mergers have heterogeneous effects depending on some borrower characteristics that proxy for their opaqueness. First, borrowers are classified by size in three categories: micro, small and medium firms in the year of entering the sample. The model is estimated for each size subsample. Second, I select the youngest firms in the sample (firms that when entering the sample are less than five years old) and estimate the model 
for young firms by size category. The results are presented table 7. The first column reproduces the results for the whole sample to facilitate comparability. Columns 2 to 4 show that there are not significant differences in the reduction of interest rates for acquirer and target borrowers by firm size. Furthermore, for the smallest firms in the sample (micro and small) the decline in interest rates appears to be even more severe than for medium firms. Columns 5 to 7 further restrict the sample to young firms. The same pattern of results shows up: young and micro firms affected by bank merger activity experience the highest reduction in interest rates, followed by young and small firms; medium firms do not appear to gain as much as the smallest and youngest firms, however, the effect on interest rates is still negative (although less significant). In sum, the evidence presented here does not support the hypothesis that mergers disproportionally harm the most informationally opaque firms; on the contrary, the smallest and youngest firms in the sample appear to be the ones receiving more gains from mergers.

\subsection{Bank size and ownership form}

There is an ongoing discussion on the effects of bank size to small business lending. Several authors argue that large banks created through mergers may not be responsive to the needs of small businesses (Peek and Rosengren 1998, Berger et al. 1998, Strahan and Weston 1998, Berger et al. 2007). The reason is that large banks may have a disadvantage in lending to small and opaque businesses. For instance, Stein (2002) argues that large banks face organizational diseconomies and hence are at a disadvantage to use and transmit soft information, which is crucial for value enhancing lending relationships.

In this section I explore which types of consolidation produce the largest changes in loan interest rates. Following Delgado et al. (2007), banks are grouped into three size classes: small ( $€ 1000$ million in total loans or less), medium (between $€ 1000$ and 25,000 million) and large (above $€ 25,000$ million). Mergers are classified into six categories according to the size of banks. The smaller bank is the target in all mergers. 
The findings are shown in panel A, table 8. Two interesting patterns arise. First, the most beneficial mergers from the borrower point of view are those involving two large banks. On average, target (acquirer) borrowers experience a reduction on interest rate of 27.6 (11) basis points. This result is quantitatively relevant because it has the potential to affect the largest number of borrowers given the size of the banks involved. Second, borrowers seem to also benefit when banks of different size merge. For instance, borrowers of a small target bank that is acquired by a large bank experience a reduction on interest rate of 23.8 basis points. This suggests that mergers of equals do not seem to benefit its borrowers as much as mergers of banks of different size, except for mergers involving two large banks. The findings in this section differ from Sapienza (2002) who finds larger declines on interest rates for borrowers of smaller target banks. However, they are consistent with Erel (2006) that documents favorable effects of large banks' mergers on small business.

As pointed out in section 2, Spanish banks differ on their form of ownership and governance structure. Out of the 40 mergers occurred in the sample period, 24 involved two commercial banks, 4 mergers occurred between two savings banks, in 8 mergers a savings bank acquired a commercial bank, and 4 involved one official credit institution. In this section I explore the heterogeneous impact that different ownership of merging banks may have on its borrowers. One would expect that clearer and well-defined property rights should imply higher economic performance and efficiency of commercial banks with respect to savings banks. However, the empirical evidence in the Spanish banking market suggests that savings and commercial banks have similar levels of productive efficiency (Grifell-Tatjé and Lovell 1997, Lozano 1998). As Crespí et al. (2004) points out, product-market competition and the possibility of being acquired by another savings bank have served as a disciplinary effect for savings banks. Delgado et al. (2007) finds that savings banks specialize relatively more in relationship loans.

The results can be found in panel B. Some interesting patterns show up. The largest reduction in interest rates is 21 basis points for target borrowers when two commercial banks merge. When a savings bank acquires another bank (commercial or savings bank), only acquiring borrowers experience a significant reduction in interest rates; target borrowers do not. For mergers involving at least one official credit entity both 
target and acquirer experience a similar decline in interest rates of about 12-14 basis points. Although some coefficients are not significant, all of them are negative, reinforcing the interpretation that mergers entail efficiency gains.

Finally, I combine the two dimensions of size and ownership form of merging banks. That is, mergers are classified in twelve categories depending on ownership and size of merging banks. Note that all mergers involving two savings banks correspond to a medium bank acquiring a small bank. This analysis may give insights as to which types of consolidation are more likely to produce the largest changes in interest rates. The results can be found in panel $\mathrm{C}$. The largest reductions in interest rates correspond to small target borrowers of commercial banks that are acquired by a large commercial banks (32 basis points). This type of merger produces large efficiency gains for target borrowers that continue the relationship with the consolidated bank. Borrowers of target small commercial banks and acquiring medium savings banks also experience significant reductions in interest rates.

\subsection{In-market mergers, out-of-market mergers and market concentration}

The results obtained so far indicate that bank mergers generate some gains which are passed on to borrowers in the form of reduced loan interest rates. Bank mergers enhance cost efficiency because the new consolidated bank may reduce costs, for example, by eliminating redundant managerial positions or closing bank branches serving the same local market. The potential for cutting costs is greater the larger the geographic overlap of merging banks. At the same time, mergers among banks with large market overlap may entail a significant increase in the local banking market concentration. Higher market power of the new consolidated bank may offset the cost saving effect from the borrower's point of view. Therefore, which of the two effects dominates is an empirical question. Mergers among banks with no market overlap do not raise concerns for increased market power and may increase efficiency of the consolidated institution by means of greater risk diversification and economies of scope.

In this section I examine the relation between loan interest rates and the degree of geographical market overlap between the target and the acquiring banks. First, I 
distinguish between in-market and out-of-market mergers. Second, I differentiate between provinces with a significant increase in banking market concentration and those without significant changes. Finally I combine the two dimensions to obtain some insights on whether merging banks with high market overlap may create some concerns for market power.

A province is affected by an in-market merger if at least two banks involved in a given merger were operating in that province when the merger occurred. A province is affected by an out-of-market merger if a bank with branches in a province is taken over by an acquirer that did not operate in that province prior to the merger. This is the same definition as in Sapienza (2002). For a given merger and given the geographical distribution of target and acquiring bank branches, some provinces are classified as inmarket merger, some provinces as out-of-market, and some other provinces are neither in-market nor out-of-market. In my merger sample, out of the 1,224 province-merger observations there are 484 in-market observations and 87 out-of-market observations. The remaining observations are provinces affected by the merger that do not satisfy the definition for in-market or out-of-market province. For instance, a bank with branches in a province takes over an acquirer that did not operate in that province prior to the merger.

The results can be found in table 9. In panel A I estimate differential effects for target and acquirer borrowers for in-market, out-of-market and other bank mergers. For inmarket mergers, we observe that target borrowers experience a large decrease in interest rates of 20.7 basis points, which confirms the hypothesis that mergers entail larger cost efficiency gains the greater the market overlap. As I argued before, target borrowers are more likely to benefit from efficiency gains because target banks are usually much more inefficient that acquirer banks. Acquiring borrowers do not benefit as much from inmarket mergers because they already had a lending relationship with a quite efficient financial institution. From out-of-market mergers the reverse pattern arises: acquirer borrowers experience a larger decrease on interest rates than target borrowers. Merger gains when there is no market overlap basically arise from greater risk diversification. Acquirer borrowers seem to benefit the most from improved risk management practices. 
Next, I divide mergers depending on the increase in the degree of concentration in the provincial banking market as measured by the provincial HHI. I use three cut points for the increase in HHI: 50, 100 and 200. For instance, one group contains provinces in which the HHI increases by more than 100 points (113 province-merger observations) and the second groups contains the remaining provinces (1,111 province-merger observations). The results can be found in panels B.1 to B.3. We observe a significant market power effect. The larger the increase in banking market concentration the lower the decline in interest rates. Nevertheless, it is worth noting that even for the provinces with the highest increase in HHI (panel B.3) the estimated effects are still negative for target borrowers and only marginally positive for acquirer borrowers (none of these effects are statistically different from zero). In light of these results, we can conclude that increases in market power determine the extent to which banks share efficiency gains with its borrowers. I do not find support for the hypothesis that market power may dominate efficiency gains as is the case in Italy (Sapienza 2002) and the U.S. (Erel 2005). None of the regression estimates shows a positive effect of mergers on interest rates, suggesting that market power effects have not been a concern in Spanish banking market.

To further check this conclusion, I divide in-market mergers in two groups: provinces in which the HHI increases by more than 100 points (113 province-merger observations) and the rest (371 province-merger observations). The results in panel $\mathrm{C}$ confirm the previous results that in-market mergers generate efficiency gains for target borrowers. The effect is smaller for mergers that increase the concentration in the local banking market. Still, the effect is negative and significant. Acquirer borrowers benefit the most from out-of-market mergers. I confirm that efficiency gains from mergers prevail over the market power effects, so that borrowers benefit from banking consolidation.

\subsection{Does selection explain the reduction in interest rates?}

The interest rate reduction for continuing borrowers could reflect a selection mechanism according to which only the higher quality firms (or firms with certain characteristics) continue the lending relationship with the consolidated bank. When the new borrower pool is added in its portfolio, the consolidated bank reduces interest rates to these high 
quality borrowers. In this section I perform a selection test and then I estimate the model correcting for this bias. ${ }^{21}$

In order to test for selection bias, one can look for pre-existing effects of the mergers. I re-estimate the original model with the MERGER(t) variable but also include the lead of this dummy MERGER(t+1) that is equal to one if one or more of the firm lenders are involved in M\&As in the following year $t+1$. In the presence of selection, the lead variable would be significantly different from zero. The null hypothesis of no effect of merger on interest rates is rejected only if the coefficient on MERGER(t) is significant and the coefficient on the pre-merger dummy MERGER $(\mathrm{t}+1)$ is either insignificant or opposite signed. The coefficient of MERGER(t) is -0.049 (significant at $1 \%$ ) and the coefficient of MERGER( $(t+1)$ is -0.004 (not significantly different from zero). This diagnostic test is consistent with no selection bias. Next, I estimate a two-stage model to correct for selection. In the first stage, I estimate a probit model for each $t$ on the probability that a firm lender is involved in a merger, i.e. the dependent variable is MERGER(t). The inverse Mills ratio of each regression is interacted with time dummies and is included in the main regression to control for selection bias. The coefficient of the MERGER(t) variable is slightly decreased to -0.040 (compared to -0.049 without correction) and remains highly significant. To estimate long term effects, we use the variable MERGER(t,T). The coefficient estimated is -0.090 (compared to -0.106 without correction). Overall, the results with correction for selection bias are consistent with those without correction. The interest rate drop for borrowers of consolidated banks does not appear to be driven by a selection bias in which acquiring banks simply identify good borrowers of poorly performing target banks.

\section{Conclusion and implications for European banking market integration}

This paper provides evidence on the costs and benefits of bank mergers to small business. On the one hand, mergers are harmful to small businesses because lending relationships are more likely to be disrupted following a merger. Small borrowers of target banks have a higher probability of losing a relationship with the consolidated

\footnotetext{
${ }^{21}$ The main results are reported in the text. The results of these regressions are available from the author upon request.
} 
bank. Moreover, small borrowers find it harder to start new lending relationship with consolidated banks. In sum, the higher termination rate for existing borrowers is not compensated with a higher initiation rate of new lending relationships with small businesses after the merger.

On the other hand, continuing borrowers benefit from mergers in terms of reduced loan rates. Small and young firms enjoy the highest decline in interest rates. The most beneficial mergers from the borrower point of view are those involving two large banks, which is not consistent with the existence of a "size effect" in lending. While the reduction in interest rates is larger when the acquirer and the target have some market overlap and, consequently, more potential for cost savings, the decline is much smaller when there is a significant increase in local banking market concentration. That is, the change in local market concentration determines the extent to which efficiency gains are passed on to borrowers. From a policy perspective, this result hints at a potential concern if banking consolidation keeps up the same pace. The degree of banking concentration in some Spanish provinces is currently quite high, the majority of banks have a presence in almost all Spanish provinces, and thus there is little room for additional out-of-market mergers within Spain. One may expect that if more in-market bank mergers occur the sign of the effect of mergers on interest rates may reverse.

Even though this study only uses Spanish data and focuses on within-country mergers, some implications can be derived for the integration of the European banking market. In particular, the analysis of in-market versus out-of-market mergers can be viewed as a control environment to compare the effects of domestic mergers versus cross-country mergers where the institutional and regulatory variables are held constant.

The predictions of the effects of domestic mergers (within borders) on small business depend on the degree of concentration of each country's banking market. In the $90 \mathrm{~s}$, many European countries experienced a wave of domestic M\&A. This consolidation process has clearly led to an increased banking concentration within individual European countries. Domestic consolidation was based on the conviction that a strong domestic market is necessary before moving abroad and on the policy of creating “national champions" (Group of Ten 2001, Boot 1999, Carbó et al. 2007). As a result, the scale and market share of banks increased within borders. In light of the results 
presented in the paper, one should expect only small benefits of domestic M\&A for small businesses.

After peaking in 1999, the value of European domestic banking deals has been in decline. Interestingly, since 2003 the value of European cross-border deals has been rising year after year. There are a number of reasons to believe that cross-border banking consolidation will increase in Europe during the coming years. The larger players in some countries are unlikely to grow through further domestic M\&A because their markets have become increasingly concentrated. For some time now, the European Commission has focused on the removal of impediments to European cross-border banking consolidation. The enlargement of the European Union is expected to increase the level of cross-border M\&A activity involving banks with an appetite for exposure to higher growth markets. Indeed, approximately one-third of the number of bank M\&A deals in Europe over the last ten years has involved banks in western Europe acquiring all or part of banks in emerging Europe (central and eastern Europe, the Commonwealth of Independent States, the Baltic States and Turkey) (Pricewaterhouse 2006). The results in the paper show that out-of-market mergers generate some efficiency gains, probably in terms of greater risk diversification, which are passed along to borrowers. In light of this analysis, one should expect that small businesses will benefit from increased cross-border M\&A. 


\section{References}

Altman, E, 1968. Financial Ratios, Discriminant Analysis and the Prediction of Corporate Bankruptcy, Journal of Finance, 23, 589-609.

Amel, D., C. Barnes, F. Panetta, and C. Salleo, 2004. Consolidation and efficiency in the financial sector: A review of the international evidence, Journal of Banking and Finance, 28, 2493-2519.

Berger, A.N. and G.F. Udell, 1995. Relationship Lending and Lines of Credit in Small Firm Finance. Journal of Business, 68, 351-381.

Berger A.N., R.J. Rosen, and G.F. Udell, 2007. Does market size structure affect competition? The case of small business lending, Journal of Banking and Finance, 31, 11-33.

Berger, A. N., A. Saunders, J. M. Scalise, and G. F. Udell, 1998. The effects of bank mergers and acquisitions on small business lending, Journal of Financial Economics, $50,187-229$.

Bonaccorsi Di Patti, E. and G. Gobbi, 2007. Winners or Losers? The Effects of Banking Consolidation on Corporate Borrowers, Journal of Finance, 62, 669-695.

Boot, A.W.A., 1999. European lessons on consolidation in banking, Journal of Banking and Finance, 23, 609-613.

Carbó Valverde, S., D.B. Humphrey, and R. Lopez del Paso, 2007. Do cross-country differences in bank efficiency support a policy of 'national champions'?, Journal of Banking and Finance, 31, 2173-2188.

Cole, R.A, 1998. The importance of relationships to the availability of credit, Journal of Banking and Finance, 22, 959-977. 
Crespí, R., M.A. García-Cestona, and V. Salas-Fumás, 2004. Governance mechanisms in Spanish banks. Does ownership matter?, Journal of Banking and Finance, 28, 23112330.

D'Auria, C., A. Foglia, P.Marullo Reedtz, 1999. Bank interest rates and credit relationships in Italy, Journal of Banking and Finance, 23, 1067-1093.

Degryse, H.A., N. Masschelein, and J. Mitchell, 2006. Staying, Dropping, or Switching: The Impacts of Bank Mergers on SMEs. TILEC Discussion Paper No. 2006-034.

Delgado, J., V. Salas-Fumás and J. Saurina, 2007. The joint size and ownership specialization in banks' lending, Journal of Banking and Finance, 31, 3563-3583.

Erel, I., 2006. The Effect of Bank Mergers on Loan Prices: Evidence from the U.S. Fisher College of Business Working Paper No. 2006-03-002.

Grifell-Tatjé, E. and C. Lovell, 1997. The sources of productivity change in Spanish banking, European Journal of Operational Research 98, 364-380.

Group of Ten, 2001. Report on consolidation in the financial sector. Bank for International Settlements, Basel, Switzerland.

Harhoff, D. and T. Körting, 1998. Lending Relationships in Germany - Empirical Evidence from Survey Data. Journal of Banking and Finance, 22, 1317-1353.

Karceski J., S. Ongena and D.C. Smith, 2005. The impact of bank consolidation on commercial borrower welfare, Journal of Finance, 60, 2043-2082.

Lozano, A., 1998. Efficiency and technical change for Spanish banks. Applied Financial Economics 8, 289-300.

Maudos, J., 1998. Market structure and performance in Spanish banking using a direct measure of effciency, Applied Financial Economics, 8, 191-200. 
Peek, J., and E. S. Rosengren, 1998. Bank consolidation and small business lending: It's not just bank size that matters, Journal of Banking and Finance 22, 799-820.

Petersen, M.A. and R.G. Rajan, 1994. The Benefits of Lending Relationships: Evidence from Small Business Data. Journal of Finance, 49, 3-37.

PricewaterhouseCoopers LLP. European banking consolidation. April 2006.

Rajan, R.G., 1992. Insiders and outsiders: The choice between informed and armslength debt, Journal of Finance, 47, 1367-1400.

Sapienza, P., 2002. The effects of banking mergers on loan contracts, Journal of Finance, 57, 329-367.

Scherr, F. and Hulburt, H., 2001. The debt maturity structure of small firms', Financial Management, 30, 85-111.

Scott J. A. and W. C. Dunkelberg, 2003. Bank Mergers and Small Firm Financing, Journal of Money, Credit and Banking, 35, 999-1017.

Sharpe, S.A. 1990. Assymetric information, bank lending, and implicit contracts: A stylized model of customer relationships Journal of Finance, 45, 1069-1087.

Stein, J.C., 2002. Information production and capital allocation: Decentralized vs. hierarchical firms, Journal of Finance, 57, 1891-1921.

Strahan, Philip. E. and James P. Weston, 1998. Small Business Lending and the Changing Structure of the Banking Industry, Journal of Banking and Finance, 22, 821845. 


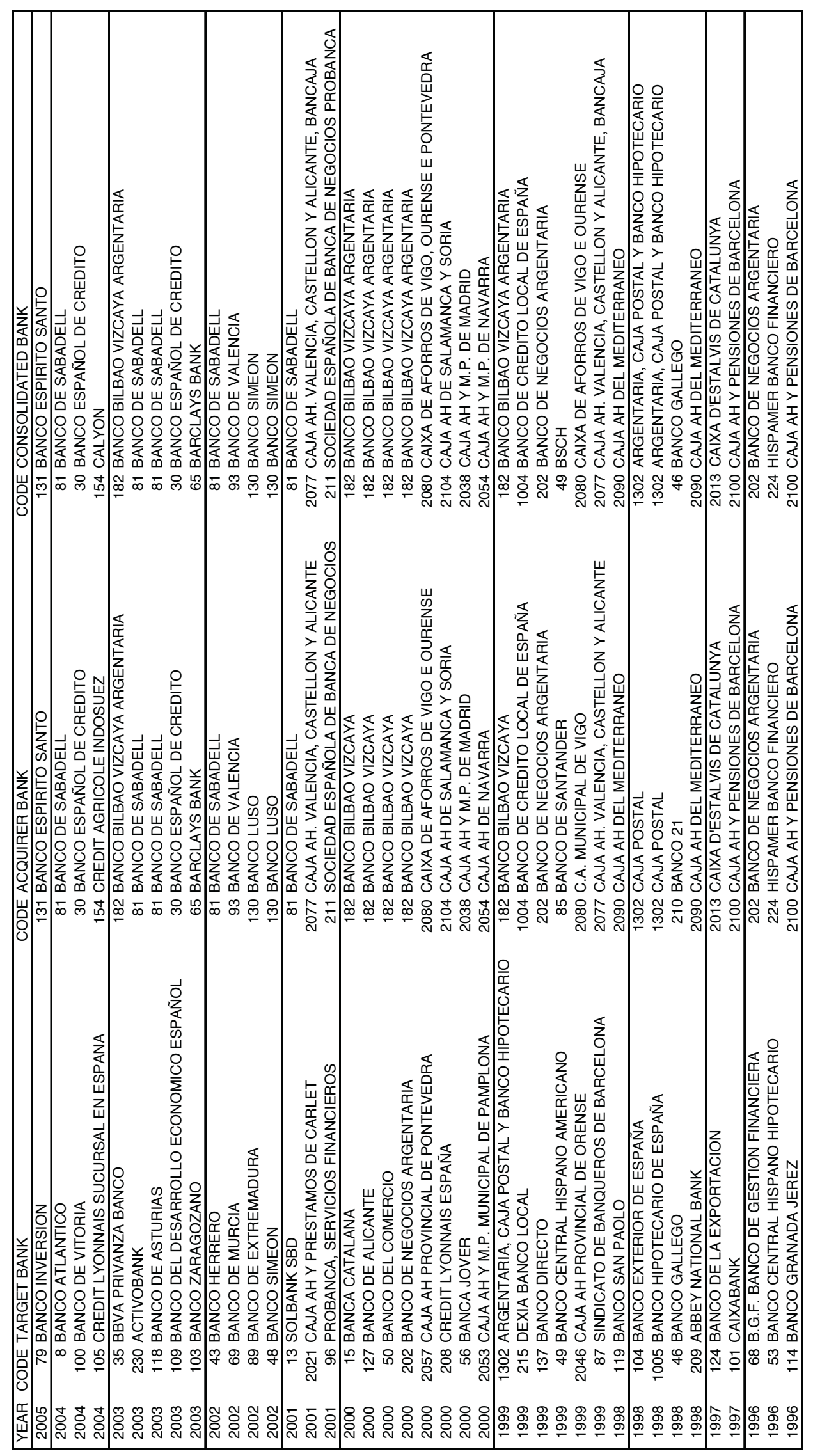


Table 2

Bank characteristics

Panel A. Target bank

\begin{tabular}{lrrrrr} 
& Obs & Mean & Std. Dev. & Min & Max \\
\hline Total assets & 40 & 6.30 & 16.29 & 0.06 & 75.88 \\
ROA & 37 & 0.01 & 3.56 & -17.70 & 6.77 \\
Capital/Assets & 35 & 7.15 & 13.52 & 0.47 & 68.57 \\
\hline
\end{tabular}

Panel B. Acquirer bank

\begin{tabular}{lrrrrr} 
& Obs & Mean & Std. Dev. & Min & Max \\
\hline Total assets & 32 & 27.76 & 39.25 & 0.33 & 175.43 \\
ROA & 31 & 0.89 & 0.48 & -0.22 & 1.97 \\
Capital/Assets & 21 & 2.97 & 4.10 & 0.34 & 16.56 \\
\hline
\end{tabular}

Panel C. Consolidated bank

\begin{tabular}{lrrrrr} 
& Obs & Mean & Std. Dev. & Min & Max \\
\hline Total assets & 32 & 37.48 & 53.16 & 0.02 & 193.57 \\
ROA & 30 & 1.05 & 1.13 & 0.07 & 6.77 \\
Capital/Assets & 21 & 2.94 & 3.41 & 0.34 & 11.44 \\
\hline
\end{tabular}

Total assets are expressed in constant 2000 euros (thousand milions). ROA is EBIT over assets. Capital is subscribed capital over assets. Target and acquirer bank observations refer to the year before the merger and consolidated bank to the year after the merger. 
Table 3

Firm characteristics

Panel A. All firms and continuing borrowers

\begin{tabular}{|c|c|c|c|c|c|c|c|c|}
\hline \multirow[t]{2}{*}{ Number of firm-year observations } & \multicolumn{2}{|c|}{$\begin{array}{l}\text { All firms } \\
(\mathrm{N}=674735)\end{array}$} & \multicolumn{2}{|c|}{$\begin{array}{l}\text { Target borrowers } \\
(\mathrm{N}=26679)\end{array}$} & \multicolumn{2}{|c|}{$\begin{array}{l}\text { Acquirer borrowers } \\
(\mathrm{N}=155855)\end{array}$} & \multicolumn{2}{|c|}{$\begin{array}{l}\text { Overlap borrowers } \\
(\mathrm{N}=4305)\end{array}$} \\
\hline & Mean & Median & Mean & Median & Mean & Median & Mean & Median \\
\hline Firm age & 13.0 & 11.0 & 15.3 & 13.0 & 13.9 & 12.0 & 19.0 & 16.0 \\
\hline Assets (1000) & 3822 & 1209 & 5573 & 2075 & 4497 & 1401 & 8213 & 4695 \\
\hline Sales (1000) & 4475 & 1816 & 6685 & 2944 & 5303 & 2067 & 10181 & 6138 \\
\hline Number of lenders & 1.98 & 2.00 & 3.10 & 3.00 & 2.50 & 2.00 & 4.69 & 4.00 \\
\hline Z-score & 3.44 & 3.17 & 3.30 & 3.04 & 3.42 & 3.16 & 3.15 & 2.93 \\
\hline Leverage & 70.15 & 73.75 & 69.49 & 72.93 & 69.07 & 72.49 & 66.91 & 70.00 \\
\hline Liquidity & 1.49 & 1.18 & 1.47 & 1.18 & 1.51 & 1.20 & 1.49 & 1.22 \\
\hline Collateral & 0.41 & 0.24 & 0.40 & 0.25 & 0.40 & 0.23 & 0.41 & 0.26 \\
\hline Firm ROA & 6.95 & 5.96 & 7.44 & 6.45 & 7.20 & 6.17 & 7.30 & 6.43 \\
\hline
\end{tabular}

Panel B. Initiation \& termination of lending relationship with consolidated bank

\begin{tabular}{|c|c|c|c|c|c|c|c|c|}
\hline \multirow[t]{2}{*}{ Number of firm-year observations } & \multicolumn{2}{|c|}{$\begin{array}{l}\text { New borrowers } \\
(\mathrm{N}=11589)\end{array}$} & \multicolumn{2}{|c|}{$\begin{array}{l}\text { Target \& terminate } \\
(\mathrm{N}=1743)\end{array}$} & \multicolumn{2}{|c|}{$\begin{array}{l}\text { Aquirer \& terminate } \\
(\mathrm{N}=4033)\end{array}$} & \multicolumn{2}{|c|}{$\begin{array}{l}\text { Overlap \& terminate } \\
(\mathrm{N}=107)\end{array}$} \\
\hline & Mean & Median & Mean & Median & Mean & Median & Mean & Median \\
\hline Firm age & 16.2 & 14.0 & 19.0 & 16.0 & 19.2 & 17.0 & 21.1 & 21.0 \\
\hline Assets (1000) & 6870 & 3210 & 8417 & 3866 & 9534 & 4854 & 14075 & 5891 \\
\hline Sales (1000) & 8096 & 4609 & 9321 & 5167 & 10673 & 6313 & 12960 & 6660 \\
\hline Number of lenders & 2.71 & 2.00 & 3.75 & 3.00 & 3.90 & 4.00 & 5.43 & 6.00 \\
\hline Z-score & 3.16 & 2.91 & 3.12 & 2.89 & 3.07 & 2.83 & 2.73 & 2.72 \\
\hline Leverage & 69.66 & 73.08 & 66.29 & 69.22 & 68.02 & 71.53 & 69.11 & 70.42 \\
\hline Liquidity & 1.42 & 1.17 & 1.53 & 1.24 & 1.46 & 1.20 & 1.39 & 1.19 \\
\hline Collateral & 0.39 & 0.26 & 0.39 & 0.25 & 0.41 & 0.27 & 0.34 & 0.23 \\
\hline Firm ROA & 7.04 & 6.07 & 6.31 & 5.48 & 6.21 & 5.29 & 5.14 & 5.70 \\
\hline
\end{tabular}

Age is the number of years since firm was founded. Assets and assets are at constant 2000 euros (in thousands). Leverage is the ratio of liabilities over assets. Liquidity is the ratio of current assets over current liabilities. Collateral is fixed assets over assets. Firm ROA is EBIT over assets. Altman Z-score is ZA $=1.2$ [working capital/assets] + 1.4 [retained earnings/assets] + 3.3 [EBIT/assets] + 0.6 [equity /liabilities] + 1 [sales/assets] . 
Table 4

Termination and initiation of lending relationships by firm characteristics

PANEL A. Terminate relationship

PANEL B. Inititate relationship

\begin{tabular}{|c|c|c|c|c|c|c|c|c|}
\hline & [1] & [2] & [3] & [4] & [5] & [6] & [7] & [8] \\
\hline Target & $\begin{array}{l}0.018^{* * *} \\
{[0.001]}\end{array}$ & & & & & & & \\
\hline Target \& D1 & & $\begin{array}{l}0.031^{\star \star *} \\
{[0.004]}\end{array}$ & $\begin{array}{l}0.021^{* * *} \\
{[0.003]}\end{array}$ & $\begin{array}{l}0.018^{\star \star \star} \\
{[0.002]}\end{array}$ & & & & \\
\hline Target \& D2 & & $\begin{array}{l}0.026^{\star \star \star} \\
{[0.002]}\end{array}$ & $\begin{array}{l}0.022^{\star * *} \\
{[0.002]}\end{array}$ & $\begin{array}{l}0.017^{\star * *} \\
{[0.002]}\end{array}$ & & & & \\
\hline Target \& D3 & & $\begin{array}{l}0.010^{\star \star \star} \\
{[0.001]}\end{array}$ & $\begin{array}{l}0.015^{\star \star *} \\
{[0.001]}\end{array}$ & $\begin{array}{l}0.022 * * * \\
{[0.002]}\end{array}$ & & & & \\
\hline Acquirer & $\begin{array}{l}-0.007^{\star \star *} \\
{[0.000]}\end{array}$ & & & & & & & \\
\hline Acquirer \& D1 & & $\begin{array}{l}-0.011^{* * *} \\
{[0.001]}\end{array}$ & $\begin{array}{l}-0.006^{* * *} \\
{[0.001]}\end{array}$ & $\begin{array}{l}-0.005^{\star * *} \\
{[0.000]}\end{array}$ & & & & \\
\hline Acquirer \& D2 & & $\begin{array}{l}-0.007^{\star \star *} \\
{[0.000]}\end{array}$ & $\begin{array}{l}-0.006^{\star \star \star} \\
{[0.000]}\end{array}$ & $\begin{array}{l}-0.007^{\star \star \star} \\
{[0.000]}\end{array}$ & & & & \\
\hline Acquirer \& D3 & & $\begin{array}{l}-0.004^{* * *} \\
{[0.000]}\end{array}$ & $\begin{array}{l}-0.007^{* * *} \\
{[0.000]}\end{array}$ & $\begin{array}{l}-0.008^{* * *} \\
{[0.000]}\end{array}$ & & & & \\
\hline Consolidated & & & & & $\begin{array}{l}-0.008^{\star \star *} \\
{[0.000]}\end{array}$ & & & \\
\hline Consolidated \& D1 & & & & & & $\begin{array}{l}-0.015^{\star \star \star} \\
{[0.001]}\end{array}$ & $\begin{array}{l}-0.008^{\star \star \star} \\
{[0.001]}\end{array}$ & $\begin{array}{l}-0.006^{\star \star \star} \\
{[0.000]}\end{array}$ \\
\hline Consolidated \& D2 & & & & & & $\begin{array}{l}-0.007^{\star * *} \\
{[0.000]}\end{array}$ & $\begin{array}{l}-0.007^{\star * * *} \\
{[0.000]}\end{array}$ & $\begin{array}{l}-0.007^{* * *} \\
{[0.000]}\end{array}$ \\
\hline Consolidated \& D3 & & & & & & $\begin{array}{l}-0.005^{\star * *} \\
{[0.001]}\end{array}$ & $\begin{array}{l}-0.009^{\star * *} \\
{[0.000]}\end{array}$ & $\begin{array}{l}-0.011^{\star * *} \\
{[0.000]}\end{array}$ \\
\hline Log firm age & $\begin{array}{l}0.004^{* * *} \\
{[0.000]}\end{array}$ & $\begin{array}{l}0.004^{* * *} \\
{[0.000]}\end{array}$ & $\begin{array}{l}0.004^{* * *} \\
{[0.000]}\end{array}$ & $\begin{array}{l}0.004^{* * *} \\
{[0.000]}\end{array}$ & $\begin{array}{l}0.001^{* * *} \\
{[0.000]}\end{array}$ & $\begin{array}{l}0.001^{* * *} \\
{[0.000]}\end{array}$ & $\begin{array}{l}0.001^{* * *} \\
{[0.000]}\end{array}$ & $\begin{array}{l}0.001^{* * *} \\
{[0.000]}\end{array}$ \\
\hline Log firm assets & $\begin{array}{l}0.002^{\star * \star} \\
{[0.000]}\end{array}$ & $\begin{array}{l}0.002^{\star \star \star} \\
{[0.000]}\end{array}$ & $\begin{array}{l}0.002^{\star \star \star} \\
{[0.000]}\end{array}$ & $\begin{array}{l}0.002^{* * *} \\
{[0.000]}\end{array}$ & $\begin{array}{l}0.001^{* * *} \\
{[0.000]}\end{array}$ & $\begin{array}{l}0.001^{\star * \star} \\
{[0.000]}\end{array}$ & $\begin{array}{l}0.001^{\star * \star} \\
{[0.000]}\end{array}$ & $\begin{array}{l}0.001^{* * *} \\
{[0.000]}\end{array}$ \\
\hline Log firm sales & $\begin{array}{l}0.004^{\star * *} \\
{[0.000]}\end{array}$ & $\begin{array}{l}0.004^{\star * \star} \\
{[0.000]}\end{array}$ & $\begin{array}{l}0.004^{* * *} \\
{[0.000]}\end{array}$ & $\begin{array}{l}0.004^{\star * *} \\
{[0.000]}\end{array}$ & $\begin{array}{l}0.005^{\star \star \star} \\
{[0.000]}\end{array}$ & $\begin{array}{l}0.005^{\star * \star} \\
{[0.000]}\end{array}$ & $\begin{array}{l}0.005^{\star * *} \\
{[0.000]}\end{array}$ & $\begin{array}{l}0.006^{\star \star *} \\
{[0.000]}\end{array}$ \\
\hline Z-score & $\begin{array}{l}-0.000^{\star \star \star} \\
{[0.000]}\end{array}$ & $\begin{array}{l}-0.000^{* \star \star} \\
{[0.000]}\end{array}$ & $\begin{array}{l}-0.000^{\star \star \star} \\
{[0.000]}\end{array}$ & $\begin{array}{l}-0.000^{\star \star \star} \\
{[0.000]}\end{array}$ & $\begin{array}{l}-0.001^{* * *} \\
{[0.000]}\end{array}$ & $\begin{array}{l}-0.001^{* \star *} \\
{[0.000]}\end{array}$ & $\begin{array}{l}-0.001^{\star \star *} \\
{[0.000]}\end{array}$ & $\begin{array}{l}-0.001^{\star \star \star} \\
{[0.000]}\end{array}$ \\
\hline Leverage & $\begin{array}{l}0.000^{\star \star \star} \\
{[0.000]}\end{array}$ & $\begin{array}{l}0.000^{\star * \star} \\
{[0.000]}\end{array}$ & $\begin{array}{l}0.000^{\star \star *} \\
{[0.000]}\end{array}$ & $\begin{array}{l}0.000^{\star * *} \\
{[0.000]}\end{array}$ & $\begin{array}{l}0.000^{\star \star *} \\
{[0.000]}\end{array}$ & $\begin{array}{l}0.000^{* * *} \\
{[0.000]}\end{array}$ & $\begin{array}{l}0.000^{\star \star *} \\
{[0.000]}\end{array}$ & $\begin{array}{l}0.000^{* * *} \\
{[0.000]}\end{array}$ \\
\hline Liquidity & $\begin{array}{l}-0.001^{* * *} \\
{[0.000]}\end{array}$ & $\begin{array}{l}-0.001^{* * *} \\
{[0.000]}\end{array}$ & $\begin{array}{l}-0.001^{* * *} \\
{[0.000]}\end{array}$ & $\begin{array}{l}-0.001^{* * *} \\
{[0.000]}\end{array}$ & $\begin{array}{l}-0.000^{\star *} \\
{[0.000]}\end{array}$ & $\begin{array}{l}-0.000^{*} \\
{[0.000]}\end{array}$ & $\begin{array}{l}-0.000^{*} \\
{[0.000]}\end{array}$ & $\begin{array}{l}-0.000^{*} \\
{[0.000]}\end{array}$ \\
\hline Collateral & $\begin{array}{l}0 \\
{[0.000]}\end{array}$ & $\begin{array}{l}0 \\
{[0.000]}\end{array}$ & $\begin{array}{l}0 \\
{[0.000]}\end{array}$ & $\begin{array}{l}0 \\
{[0.000]}\end{array}$ & $\begin{array}{l}0.001^{\star *} \\
{[0.000]}\end{array}$ & $\begin{array}{l}0.001^{* *} \\
{[0.000]}\end{array}$ & $\begin{array}{l}0.001^{* *} \\
{[0.000]}\end{array}$ & $\begin{array}{l}0.001^{\star *} \\
{[0.000]}\end{array}$ \\
\hline Firm ROA & $\begin{array}{l}0 \\
{[0.000]}\end{array}$ & $\begin{array}{l}0 \\
{[0.000]}\end{array}$ & $\begin{array}{l}0 \\
{[0.000]}\end{array}$ & $\begin{array}{l}0 \\
{[0.000]}\end{array}$ & $\begin{array}{l}0 \\
{[0.000]}\end{array}$ & $\begin{array}{l}0 \\
{[0.000]}\end{array}$ & $\begin{array}{l}0 \\
{[0.000]}\end{array}$ & $\begin{array}{l}0 \\
{[0.000]}\end{array}$ \\
\hline Number of lenders & $\begin{array}{l}0.006^{\star \star \star} \\
{[0.000]}\end{array}$ & $\begin{array}{l}0.006^{\star \star \star} \\
{[0.000]}\end{array}$ & $\begin{array}{l}0.006^{\star \star \star} \\
{[0.000]}\end{array}$ & $\begin{array}{l}0.006^{\star * *} \\
{[0.000]}\end{array}$ & $\begin{array}{l}0.006^{\star * \star} \\
{[0.000]}\end{array}$ & $\begin{array}{l}0.006^{\star \star \star} \\
{[0.000]}\end{array}$ & $\begin{array}{l}0.006^{\star * *} \\
{[0.000]}\end{array}$ & $\begin{array}{l}0.006^{\star * *} \\
{[0.000]}\end{array}$ \\
\hline Log lender assets & $\begin{array}{l}-0.001^{* * *} \\
{[0.000]}\end{array}$ & $\begin{array}{l}-0.001^{* * *} \\
{[0.000]}\end{array}$ & $\begin{array}{l}-0.001^{* * *} \\
{[0.000]}\end{array}$ & $\begin{array}{l}-0.001^{* * *} \\
{[0.000]}\end{array}$ & $\begin{array}{l}0 \\
{[0.000]}\end{array}$ & $\begin{array}{l}0 \\
{[0.000]}\end{array}$ & $\begin{array}{l}0 \\
{[0.000]}\end{array}$ & $\begin{array}{l}0 \\
{[0.000]}\end{array}$ \\
\hline Lender ROA & $\begin{array}{l}-0.372^{\star \star \star} \\
{[0.021]}\end{array}$ & $\begin{array}{l}-0.372^{\star \star \star} \\
{[0.021]}\end{array}$ & $\begin{array}{l}-0.372^{\star \star \star} \\
{[0.021]}\end{array}$ & $\begin{array}{l}-0.372^{\star \star \star} \\
{[0.021]}\end{array}$ & $\begin{array}{l}-0.275^{\star \star \star} \\
{[0.024]}\end{array}$ & $\begin{array}{l}-0.276^{\star \star \star} \\
{[0.024]}\end{array}$ & $\begin{array}{l}-0.274^{\star * *} \\
{[0.024]}\end{array}$ & $\begin{array}{l}-0.275^{\star \star \star} \\
{[0.024]}\end{array}$ \\
\hline Medium lender $(0,1)$ & $\begin{array}{l}-0.015^{\star * *} \\
{[0.001]}\end{array}$ & $\begin{array}{l}-0.015^{* * *} \\
{[0.001]}\end{array}$ & $\begin{array}{l}-0.015^{\star * *} \\
{[0.001]}\end{array}$ & $\begin{array}{l}-0.015^{\star * *} \\
{[0.001]}\end{array}$ & $\begin{array}{l}-0.003^{* * *} \\
{[0.001]}\end{array}$ & $\begin{array}{l}-0.003^{\star * *} \\
{[0.001]}\end{array}$ & $\begin{array}{l}-0.003^{\star * *} \\
{[0.001]}\end{array}$ & $\begin{array}{l}-0.003^{\star * *} \\
{[0.001]}\end{array}$ \\
\hline Large lender $(0,1)$ & $\begin{array}{l}-0.012^{\star \star \star} \\
{[0.001]}\end{array}$ & $\begin{array}{l}-0.012^{\star \star \star} \\
{[0.001]}\end{array}$ & $\begin{array}{l}-0.012^{\star \star \star} \\
{[0.001]}\end{array}$ & $\begin{array}{l}-0.012^{\star \star \star} \\
{[0.001]}\end{array}$ & $\begin{array}{l}-0.009^{* * *} \\
{[0.001]}\end{array}$ & $\begin{array}{l}-0.009^{* \star *} \\
{[0.001]}\end{array}$ & $\begin{array}{l}-0.009^{\star * *} \\
{[0.001]}\end{array}$ & $\begin{array}{l}-0.009^{\star \star \star} \\
{[0.001]}\end{array}$ \\
\hline Observations & 1142521 & 1142521 & 1142521 & 1142521 & 1142521 & 1142521 & 1142521 & 1142521 \\
\hline $\begin{array}{l}\text { Chi2 test tar1=tar3 } \\
\text { p-value }\end{array}$ & & $\begin{array}{l}39.24 \\
0.000\end{array}$ & $\begin{array}{l}4.889 \\
0.027\end{array}$ & $\begin{array}{l}2.813 \\
0.094\end{array}$ & & & & \\
\hline
\end{tabular}

Probit estimates. Marginal effects on the probability of discontinuing the lending relationship evaluated at the sample mean of the explanatory variables. The dependent variable in Panel A is Terminate relationship that equals one in year $\mathrm{t}$ if firm i does not report having a relationship with bank $\mathrm{k}$ in year $\mathrm{t}+1$. In Panel $\mathrm{B}$ the dependent variable Initiate relationship equals one in year $\mathrm{t}$ if firm i did not report having a relationship with bank $\mathrm{k}$ in year $\mathrm{t}-1$. In columns $2-4$ the model is estimated with the variables Target borrower. Acquirer borrower and Consolidated borrower interacted with three dummy variables (D1, D2, D3) defined according to firm characteristics. Column 2-borrower size (micro, small, medium), 3-firm age, 4-zscore. In Panel A, the last two rows present the Chi2 test for the equality of Target*D1 and Target*D3. The regressions also include 9 year dummies and 51 province dummies. Robust standard errors in brackets. ${ }^{* *} p<0.01,{ }^{* *} p<0.05,{ }^{*} p<0.1$ 
Table 5

Temporary and permanent effects of lender mergers on interest rates

\begin{tabular}{|c|c|c|c|c|c|c|c|}
\hline & [1] & [2] & [3] & [4] & [5] & [6] & [7] \\
\hline Merger (t) & $\begin{array}{l}-0.049^{* \star \star} \\
{[0.010]}\end{array}$ & & $\begin{array}{l}-0.109^{\star \star \star} \\
{[0.017]}\end{array}$ & & & & \\
\hline Merger $(t, T)$ & & $\begin{array}{l}-0.106^{\star * *} \\
{[0.017]}\end{array}$ & & & & & \\
\hline Merger $(t+1, T)$ & & & $\begin{array}{l}-0.097^{\star \star \star} \\
{[0.019]}\end{array}$ & & & & \\
\hline Target $(\mathrm{t}, \mathrm{T})$ & & & & $\begin{array}{l}-0.198^{\star \star \star} \\
{[0.035]}\end{array}$ & & $\begin{array}{l}-0.179^{\star \star \star} \\
{[0.034]}\end{array}$ & $\begin{array}{l}-0.195^{\star \star \star} \\
{[0.035]}\end{array}$ \\
\hline Acquirer $(t, T)$ & & & & $\begin{array}{l}-0.090^{\star \star \star} \\
{[0.016]}\end{array}$ & & $\begin{array}{l}-0.080^{\star \star *} \\
{[0.016]}\end{array}$ & $\begin{array}{l}-0.102^{\star \star \star} \\
{[0.016]}\end{array}$ \\
\hline Target $(\mathrm{t})$ & & & & & $\begin{array}{l}-0.146^{\star * *} \\
{[0.028]}\end{array}$ & & \\
\hline Acquirer $(\mathrm{t})$ & & & & & $\begin{array}{l}-0.092^{\star * \star} \\
{[0.015]}\end{array}$ & & \\
\hline Target $(t+1, T)$ & & & & & $\begin{array}{l}-0.224^{* * *} \\
{[0.040]}\end{array}$ & & \\
\hline Acquirer $(t+1, T)$ & & & & & $\begin{array}{l}-0.082^{* * *} \\
{[0.020]}\end{array}$ & & \\
\hline Overlap $(\mathrm{t}, \mathrm{T})$ & & & & & & $\begin{array}{l}-0.223^{* * *} \\
{[0.030]}\end{array}$ & $\begin{array}{l}-0.270^{* * *} \\
{[0.058]}\end{array}$ \\
\hline Number of lenders & $\begin{array}{l}0.015^{\star \star} \\
{[0.006]}\end{array}$ & $\begin{array}{l}0.014^{* *} \\
{[0.006]}\end{array}$ & $\begin{array}{l}0.014^{\star *} \\
{[0.006]}\end{array}$ & $\begin{array}{l}0.006 \\
{[0.006]}\end{array}$ & $\begin{array}{l}0.004 \\
{[0.006]}\end{array}$ & $\begin{array}{l}0.001 \\
{[0.006]}\end{array}$ & $\begin{array}{l}-0.002 \\
{[0.009]}\end{array}$ \\
\hline Average assets of lenders & $\begin{array}{l}-0.727^{* *} \\
{[0.351]}\end{array}$ & $\begin{array}{l}-0.376 \\
{[0.310]}\end{array}$ & $\begin{array}{l}-0.424 \\
{[0.330]}\end{array}$ & $\begin{array}{l}-0.05 \\
{[0.274]}\end{array}$ & $\begin{array}{l}0.084 \\
{[0.290]}\end{array}$ & $\begin{array}{l}-0.073 \\
{[0.271]}\end{array}$ & $\begin{array}{l}-0.054 \\
{[0.328]}\end{array}$ \\
\hline Average ROA of lenders & $\begin{array}{l}-4.700^{\star \star \star} \\
{[1.720]}\end{array}$ & $\begin{array}{l}-3.967^{\star \star} \\
{[1.699]}\end{array}$ & $\begin{array}{l}-4.101^{\star \star} \\
{[1.734]}\end{array}$ & $\begin{array}{l}-2.687^{\star} \\
{[1.533]}\end{array}$ & $\begin{array}{l}-2.214 \\
{[1.552]}\end{array}$ & $\begin{array}{l}-2.646^{\star} \\
{[1.525]}\end{array}$ & $\begin{array}{l}-2.17 \\
{[1.494]}\end{array}$ \\
\hline $\mathrm{HHI}$ in province & $\begin{array}{l}1.17 \\
{[1.165]}\end{array}$ & $\begin{array}{l}1.288 \\
{[1.168]}\end{array}$ & $\begin{array}{l}1.267 \\
{[1.174]}\end{array}$ & $\begin{array}{l}1.393 \\
{[1.176]}\end{array}$ & $\begin{array}{l}1.426 \\
{[1.181]}\end{array}$ & $\begin{array}{l}1.375 \\
{[1.174]}\end{array}$ & $\begin{array}{l}1.258 \\
{[1.277]}\end{array}$ \\
\hline Log firm age & $\begin{array}{l}0.127^{\star \star \star \star} \\
{[0.015]}\end{array}$ & $\begin{array}{l}0.125^{\star \star \star} \\
{[0.014]}\end{array}$ & $\begin{array}{l}0.125^{\star \star \star} \\
{[0.015]}\end{array}$ & $\begin{array}{l}0.115^{\star \star \star} \\
{[0.015]}\end{array}$ & $\begin{array}{l}0.113^{\star \star \star} \\
{[0.015]}\end{array}$ & $\begin{array}{l}0.112^{\star \star \star} \\
{[0.015]}\end{array}$ & $\begin{array}{l}0.101^{\star \star \star} \\
{[0.016]}\end{array}$ \\
\hline Log firm assets & $\begin{array}{l}-0.413^{\star \star \star} \\
{[0.049]}\end{array}$ & $\begin{array}{l}-0.413^{\star \star *} \\
{[0.049]}\end{array}$ & $\begin{array}{l}-0.413^{\star * *} \\
{[0.049]}\end{array}$ & $\begin{array}{l}-0.414^{* \star \star} \\
{[0.049]}\end{array}$ & $\begin{array}{l}-0.414^{\star \star *} \\
{[0.049]}\end{array}$ & $\begin{array}{l}-0.414^{* \star *} \\
{[0.049]}\end{array}$ & $\begin{array}{l}-0.414^{* * *} \\
{[0.050]}\end{array}$ \\
\hline Log firm sales & $\begin{array}{l}0.039^{\star \star} \\
{[0.019]}\end{array}$ & $\begin{array}{l}0.039^{\star *} \\
{[0.019]}\end{array}$ & $\begin{array}{l}0.039^{\star *} \\
{[0.019]}\end{array}$ & $\begin{array}{l}0.040^{* *} \\
{[0.019]}\end{array}$ & $\begin{array}{l}0.040^{\star \star} \\
{[0.019]}\end{array}$ & $\begin{array}{l}0.040^{\star *} \\
{[0.019]}\end{array}$ & $\begin{array}{l}0.045^{\star \star} \\
{[0.020]}\end{array}$ \\
\hline Z-score & $\begin{array}{l}0.020^{\star \star} \\
{[0.008]}\end{array}$ & $\begin{array}{l}0.020^{\star \star} \\
{[0.008]}\end{array}$ & $\begin{array}{l}0.020^{\star \star} \\
{[0.008]}\end{array}$ & $\begin{array}{l}0.020^{* *} \\
{[0.008]}\end{array}$ & $\begin{array}{l}0.020^{\star *} \\
{[0.008]}\end{array}$ & $\begin{array}{l}0.020^{\star *} \\
{[0.008]}\end{array}$ & $\begin{array}{l}0.020^{\star \star} \\
{[0.008]}\end{array}$ \\
\hline Leverage & $\begin{array}{l}0.005^{\star * \star} \\
{[0.001]}\end{array}$ & $\begin{array}{l}0.005^{\star \star \star} \\
{[0.001]}\end{array}$ & $\begin{array}{l}0.005^{\star * *} \\
{[0.001]}\end{array}$ & $\begin{array}{l}0.005^{\star * *} \\
{[0.001]}\end{array}$ & $\begin{array}{l}0.005^{\star \star \star} \\
{[0.001]}\end{array}$ & $\begin{array}{l}0.005^{\star * *} \\
{[0.001]}\end{array}$ & $\begin{array}{l}0.005^{\star \star *} \\
{[0.001]}\end{array}$ \\
\hline Liquidity & $\begin{array}{l}0.129^{\star \star \star *} \\
{[0.009]}\end{array}$ & $\begin{array}{l}0.129^{\star \star \star} \\
{[0.009]}\end{array}$ & $\begin{array}{l}0.129^{\star \star * *} \\
{[0.009]}\end{array}$ & $\begin{array}{l}0.129^{\star \star \star} \\
{[0.009]}\end{array}$ & $\begin{array}{l}0.128^{\star \star \star \star} \\
{[0.009]}\end{array}$ & $\begin{array}{l}0.128^{\star \star \star} \\
{[0.009]}\end{array}$ & $\begin{array}{l}0.130^{\star \star \star} \\
{[0.009]}\end{array}$ \\
\hline Collateral & $\begin{array}{l}0.289^{\star \star \star *} \\
{[0.025]}\end{array}$ & $\begin{array}{l}0.289^{\star \star \star} \\
{[0.025]}\end{array}$ & $\begin{array}{l}0.289^{\star \star \star \star} \\
{[0.025]}\end{array}$ & $\begin{array}{l}0.289^{\star \star \star} \\
{[0.025]}\end{array}$ & $\begin{array}{l}0.289^{\star * \star *} \\
{[0.025]}\end{array}$ & $\begin{array}{l}0.289^{\star \star \star} \\
{[0.025]}\end{array}$ & $\begin{array}{l}0.284^{\star \star \star} \\
{[0.030]}\end{array}$ \\
\hline Firm ROA & $\begin{array}{l}0.018^{\star \star \star} \\
{[0.002]}\end{array}$ & $\begin{array}{l}0.018^{\star \star \star} \\
{[0.002]}\end{array}$ & $\begin{array}{l}0.018^{\star \star \star} \\
{[0.002]}\end{array}$ & $\begin{array}{l}0.018^{\star \star \star} \\
{[0.002]}\end{array}$ & $\begin{array}{l}0.018^{\star * *} \\
{[0.002]}\end{array}$ & $\begin{array}{l}0.018^{\star \star \star *} \\
{[0.002]}\end{array}$ & $\begin{array}{l}0.018^{\star \star \star} \\
{[0.002]}\end{array}$ \\
\hline R-squared & 0.19 & 0.19 & 0.19 & 0.19 & 0.19 & 0.19 & 0.18 \\
\hline Observations & 674735 & 674735 & 674735 & 674735 & 674735 & 674735 & 577351 \\
\hline Number of firms & 124213 & 124213 & 124213 & 124213 & 124213 & 124213 & 112203 \\
\hline
\end{tabular}

The dependent variable is the average interest rate paid by firm $i$ at time $t$. The regression is estimated with firm fixed effects. The regression also includes 9 year dummies. Standard errors clustered at the province level in brackets.

${ }^{*}$ significant at $10 \% ;{ }^{* *}$ significant at $5 \%$; ${ }^{* * *}$ significant at $1 \%$ 
Table 6

Continuing, terminating and switching lending relationships

\begin{tabular}{|c|c|c|c|c|c|c|c|}
\hline & [1] & [2] & [3] & [4] & [5] & [6] & [7] \\
\hline Target \& Continue & $\begin{array}{l}-0.179^{\star \star \star} \\
{[0.034]}\end{array}$ & $\begin{array}{l}-0.177^{\star \star \star} \\
{[0.034]}\end{array}$ & $\begin{array}{l}-0.195^{\star \star \star} \\
{[0.035]}\end{array}$ & $\begin{array}{l}-0.177^{\star * \star} \\
{[0.034]}\end{array}$ & $\begin{array}{l}-0.195^{\star \star \star} \\
{[0.035]}\end{array}$ & $\begin{array}{l}-0.179^{\star \star \star} \\
{[0.034]}\end{array}$ & $\begin{array}{l}-0.177^{\star \star \star} \\
{[0.034]}\end{array}$ \\
\hline Acquirer \& Continue & $\begin{array}{l}-0.080^{* \star *} \\
{[0.016]}\end{array}$ & $\begin{array}{l}-0.079^{\star * *} \\
{[0.016]}\end{array}$ & $\begin{array}{l}-0.102^{\star * *} \\
{[0.016]}\end{array}$ & $\begin{array}{l}-0.079^{\star * *} \\
{[0.016]}\end{array}$ & $\begin{array}{l}-0.102^{\star * *} \\
{[0.016]}\end{array}$ & $\begin{array}{l}-0.080^{\star * *} \\
{[0.016]}\end{array}$ & $\begin{array}{l}-0.079^{\star * *} \\
{[0.016]}\end{array}$ \\
\hline Overlap \& Continue & $\begin{array}{l}-0.223^{\star \star *} \\
{[0.030]}\end{array}$ & $\begin{array}{l}-0.223^{\star * *} \\
{[0.030]}\end{array}$ & $\begin{array}{l}-0.270^{\star * *} \\
{[0.058]}\end{array}$ & $\begin{array}{l}-0.224^{* * *} \\
{[0.030]}\end{array}$ & $\begin{array}{l}-0.272^{* * *} \\
{[0.057]}\end{array}$ & & \\
\hline Target \& Terminate & & $\begin{array}{l}-0.084^{\star *} \\
{[0.040]}\end{array}$ & $\begin{array}{l}-0.074 \\
{[0.056]}\end{array}$ & & & & $\begin{array}{l}-0.083^{\star *} \\
{[0.040]}\end{array}$ \\
\hline Acquirer \& Terminate & & $\begin{array}{l}-0.067 \\
{[0.041]}\end{array}$ & $\begin{array}{l}-0.017 \\
{[0.045]}\end{array}$ & & & & $\begin{array}{l}-0.067 \\
{[0.040]}\end{array}$ \\
\hline Overlap \& Terminate & & $\begin{array}{l}-0.128 \\
{[0.225]}\end{array}$ & $\begin{array}{l}0.210 \\
{[0.199]}\end{array}$ & & & & \\
\hline Target \& Terminate \& Switch & & & & $\begin{array}{l}-0.05 \\
{[0.068]}\end{array}$ & $\begin{array}{l}-0.062 \\
{[0.088]}\end{array}$ & & \\
\hline Acquirer \& Terminate \& Switch & & & & $\begin{array}{l}-0.045 \\
{[0.034]}\end{array}$ & $\begin{array}{l}0.056 \\
{[0.045]}\end{array}$ & & \\
\hline Overlap \& Terminate \& Switch & & & & $\begin{array}{l}-0.088 \\
{[0.254]}\end{array}$ & $\begin{array}{l}0.132 \\
{[0.321]}\end{array}$ & & $\begin{array}{l}0.000 \\
{[0.000]}\end{array}$ \\
\hline Target \& Terminate \& No Switch & & & & $\begin{array}{l}-0.112^{\star *} \\
{[0.055]}\end{array}$ & $\begin{array}{l}-0.085 \\
{[0.059]}\end{array}$ & & \\
\hline Acquirer \& Terminate \& No Switch & & & & $\begin{array}{l}-0.093 \\
{[0.064]}\end{array}$ & $\begin{array}{l}-0.103 \\
{[0.076]}\end{array}$ & & \\
\hline Overlap \& Terminate \& No Switch & & & & $\begin{array}{l}-0.208 \\
{[0.271]}\end{array}$ & $\begin{array}{l}0.279 \\
{[0.264]}\end{array}$ & & $\begin{array}{l}0.000 \\
{[0.000]}\end{array}$ \\
\hline Overlap \& Continue \& Switch & & & & & & $\begin{array}{l}-0.218^{\star *} \\
{[0.094]}\end{array}$ & $\begin{array}{l}-0.210^{* *} \\
{[0.094]}\end{array}$ \\
\hline Overlap \& Continue \& No Switch & & & & & & $\begin{array}{l}-0.227^{\star * *} \\
{[0.037]}\end{array}$ & $\begin{array}{l}-0.227^{\star * *} \\
{[0.037]}\end{array}$ \\
\hline Number of lenders & $\begin{array}{l}0.001 \\
{[0.006]}\end{array}$ & $\begin{array}{l}-0.003 \\
{[0.007]}\end{array}$ & $\begin{array}{l}-0.003 \\
{[0.010]}\end{array}$ & $\begin{array}{l}-0.004 \\
{[0.007]}\end{array}$ & $\begin{array}{l}-0.005 \\
{[0.010]}\end{array}$ & $\begin{array}{l}0.000 \\
{[0.006]}\end{array}$ & $\begin{array}{l}-0.003 \\
{[0.007]}\end{array}$ \\
\hline Average assets of lenders & $\begin{array}{l}-0.073 \\
{[0.271]}\end{array}$ & $\begin{array}{l}-0.082 \\
{[0.271]}\end{array}$ & $\begin{array}{l}-0.053 \\
{[0.329]}\end{array}$ & $\begin{array}{l}-0.08 \\
{[0.270]}\end{array}$ & $\begin{array}{l}-0.051 \\
{[0.329]}\end{array}$ & $\begin{array}{l}-0.073 \\
{[0.269]}\end{array}$ & $\begin{array}{l}-0.081 \\
{[0.268]}\end{array}$ \\
\hline Average ROA of lenders & $\begin{array}{l}-2.646^{\star} \\
{[1.525]}\end{array}$ & $\begin{array}{l}-2.628^{\star} \\
{[1.522]}\end{array}$ & $\begin{array}{l}-2.158 \\
{[1.490]}\end{array}$ & $\begin{array}{l}-2.633^{\star} \\
{[1.525]}\end{array}$ & $\begin{array}{l}-2.163 \\
{[1.486]}\end{array}$ & $\begin{array}{l}-2.633^{*} \\
{[1.521]}\end{array}$ & $\begin{array}{l}-2.617^{\star} \\
{[1.519]}\end{array}$ \\
\hline $\mathrm{HHI}$ in province & $\begin{array}{l}1.375 \\
{[1.174]}\end{array}$ & $\begin{array}{l}1.379 \\
{[1.176]}\end{array}$ & $\begin{array}{l}1.253 \\
{[1.278]}\end{array}$ & $\begin{array}{l}1.377 \\
{[1.176]}\end{array}$ & $\begin{array}{l}1.256 \\
{[1.277]}\end{array}$ & $\begin{array}{l}1.374 \\
{[1.174]}\end{array}$ & $\begin{array}{l}1.378 \\
{[1.176]}\end{array}$ \\
\hline Log firm age & $\begin{array}{l}0.112^{\star \star \star} \\
{[0.015]}\end{array}$ & $\begin{array}{l}0.110^{\star \star \star} \\
{[0.015]}\end{array}$ & $\begin{array}{l}0.100^{\star \star \star} \\
{[0.016]}\end{array}$ & $\begin{array}{l}0.110^{\star \star \star} \\
{[0.015]}\end{array}$ & $\begin{array}{l}0.100^{\star \star \star} \\
{[0.016]}\end{array}$ & $\begin{array}{l}0.112^{\star \star \star} \\
{[0.015]}\end{array}$ & $\begin{array}{l}0.110^{\star \star \star} \\
{[0.015]}\end{array}$ \\
\hline Log firm assets & $\begin{array}{l}-0.414^{\star \star \star} \\
{[0.049]}\end{array}$ & $\begin{array}{l}-0.413^{\star \star \star} \\
{[0.049]}\end{array}$ & $\begin{array}{l}-0.414^{\star \star \star} \\
{[0.050]}\end{array}$ & $\begin{array}{l}-0.413^{\star \star \star} \\
{[0.049]}\end{array}$ & $\begin{array}{l}-0.414^{\star \star \star} \\
{[0.050]}\end{array}$ & $\begin{array}{l}-0.414^{\star \star \star} \\
{[0.049]}\end{array}$ & $\begin{array}{l}-0.413^{\star \star \star} \\
{[0.049]}\end{array}$ \\
\hline Log firm sales & $\begin{array}{l}0.040^{\star *} \\
{[0.019]}\end{array}$ & $\begin{array}{l}0.040^{\star *} \\
{[0.019]}\end{array}$ & $\begin{array}{l}0.045^{\star \star} \\
{[0.020]}\end{array}$ & $\begin{array}{l}0.040^{\star *} \\
{[0.019]}\end{array}$ & $\begin{array}{l}0.045^{\star \star} \\
{[0.020]}\end{array}$ & $\begin{array}{l}0.040^{\star \star} \\
{[0.019]}\end{array}$ & $\begin{array}{l}0.040^{\star *} \\
{[0.019]}\end{array}$ \\
\hline Z-score & $\begin{array}{l}0.020^{\star *} \\
{[0.008]}\end{array}$ & $\begin{array}{l}0.020^{\star *} \\
{[0.008]}\end{array}$ & $\begin{array}{l}0.020^{\star *} \\
{[0.008]}\end{array}$ & $\begin{array}{l}0.020^{* *} \\
{[0.008]}\end{array}$ & $\begin{array}{l}0.020^{* *} \\
{[0.008]}\end{array}$ & $\begin{array}{l}0.020^{\star *} \\
{[0.008]}\end{array}$ & $\begin{array}{l}0.020^{\star *} \\
{[0.008]}\end{array}$ \\
\hline Leverage & $\begin{array}{l}0.005^{\star \star \star} \\
{[0.001]}\end{array}$ & $\begin{array}{l}0.005^{\star \star \star} \\
{[0.001]}\end{array}$ & $\begin{array}{l}0.005^{\star \star \star} \\
{[0.001]}\end{array}$ & $\begin{array}{l}0.005^{\star \star \star} \\
{[0.001]}\end{array}$ & $\begin{array}{l}0.005^{\star \star \star} \\
{[0.001]}\end{array}$ & $\begin{array}{l}0.005^{\star \star \star} \\
{[0.001]}\end{array}$ & $\begin{array}{l}0.005^{\star \star \star} \\
{[0.001]}\end{array}$ \\
\hline Liquidity & $\begin{array}{l}0.128^{\star * \star} \\
{[0.009]}\end{array}$ & $\begin{array}{l}0.128^{\star * *} \\
{[0.009]}\end{array}$ & $\begin{array}{l}0.130^{\star \star *} \\
{[0.009]}\end{array}$ & $\begin{array}{l}0.128^{\star * *} \\
{[0.009]}\end{array}$ & $\begin{array}{l}0.130^{\star \star \star} \\
{[0.009]}\end{array}$ & $\begin{array}{l}0.128^{\star * \star} \\
{[0.009]}\end{array}$ & $\begin{array}{l}0.128^{\star \star \star} \\
{[0.009]}\end{array}$ \\
\hline Collateral & $\begin{array}{l}0.289^{\star \star \star} \\
{[0.025]}\end{array}$ & $\begin{array}{l}0.289^{\star \star \star} \\
{[0.025]}\end{array}$ & $\begin{array}{l}0.284^{\star \star \star} \\
{[0.030]}\end{array}$ & $\begin{array}{l}0.289^{\star \star \star} \\
{[0.025]}\end{array}$ & $\begin{array}{l}0.284^{\star \star \star} \\
{[0.030]}\end{array}$ & $\begin{array}{l}0.289^{\star \star \star} \\
{[0.025]}\end{array}$ & $\begin{array}{l}0.289^{\star \star \star} \\
{[0.025]}\end{array}$ \\
\hline Firm ROA & $\begin{array}{l}0.018^{\star \star *} \\
{[0.002]}\end{array}$ & $\begin{array}{l}0.018^{\star * \star} \\
{[0.002]}\end{array}$ & $\begin{array}{l}0.018^{\star * *} \\
{[0.002]}\end{array}$ & $\begin{array}{l}0.018^{\star \star \star} \\
{[0.002]}\end{array}$ & $\begin{array}{l}0.018^{\star \star *} \\
{[0.002]}\end{array}$ & $\begin{array}{l}0.018^{\star \star \star} \\
{[0.002]}\end{array}$ & $\begin{array}{l}0.018^{\star \star \star} \\
{[0.002]}\end{array}$ \\
\hline R-squared & 0.19 & 0.19 & 0.18 & 0.19 & 0.18 & 0.19 & 0.19 \\
\hline Observations & 674735 & 674735 & 577351 & 674735 & 577351 & 674735 & 674735 \\
\hline Number of firms & 124213 & 124213 & 112203 & 124213 & 112203 & 124213 & 124213 \\
\hline
\end{tabular}

The dependent variable is the average interest rate paid by firm I at time $t$. The regression is estimated with firm fixed effects. The regression also includes 9 year dummies. Standard errors clustered at the province level in brackets.

*significant at $10 \% ;{ }^{* *}$ significant at $5 \%$; ${ }^{* \star *}$ significant at $1 \%$ 
Table 7

Effect of lender mergers on interest rates by borrower size and age

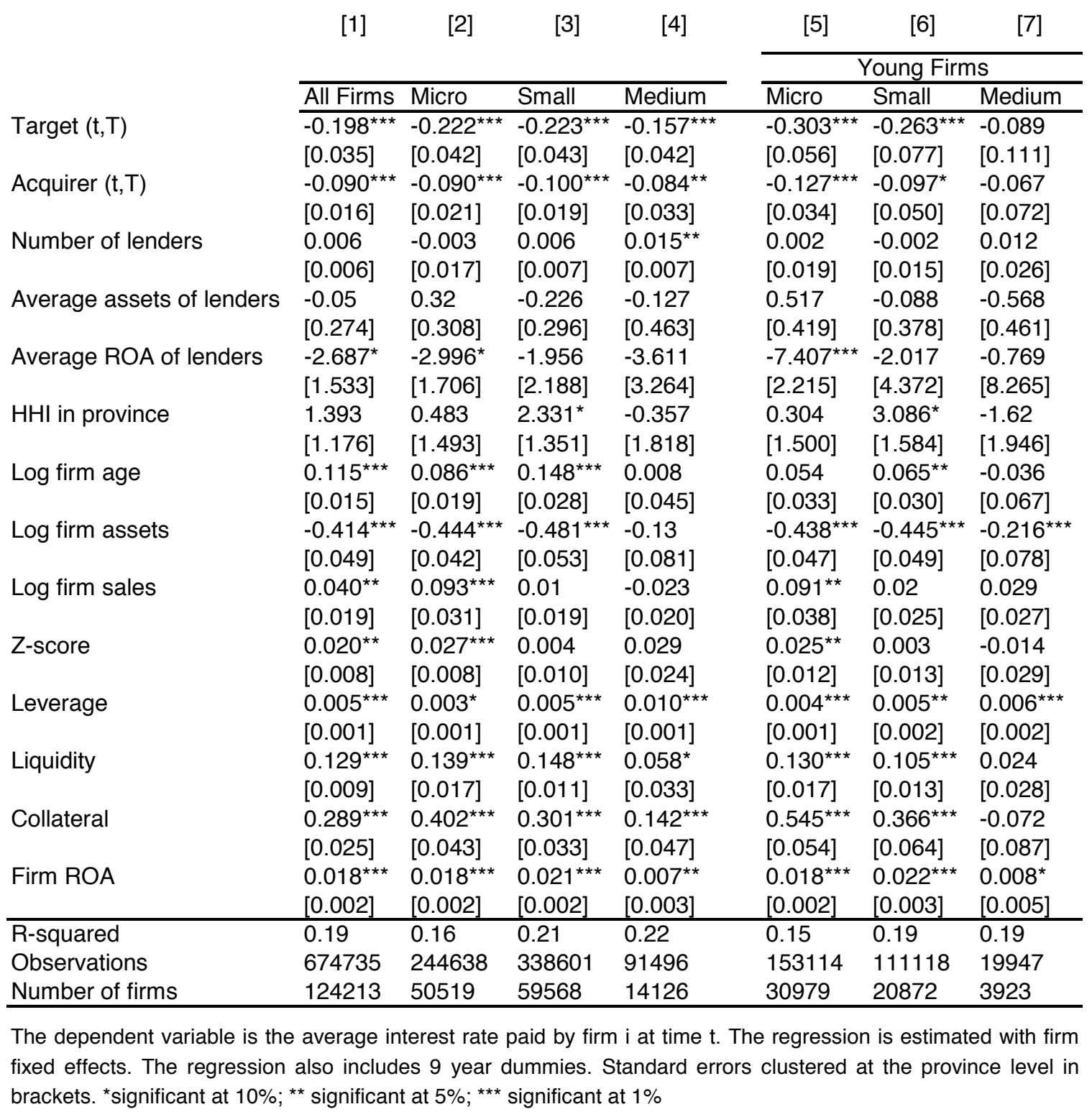




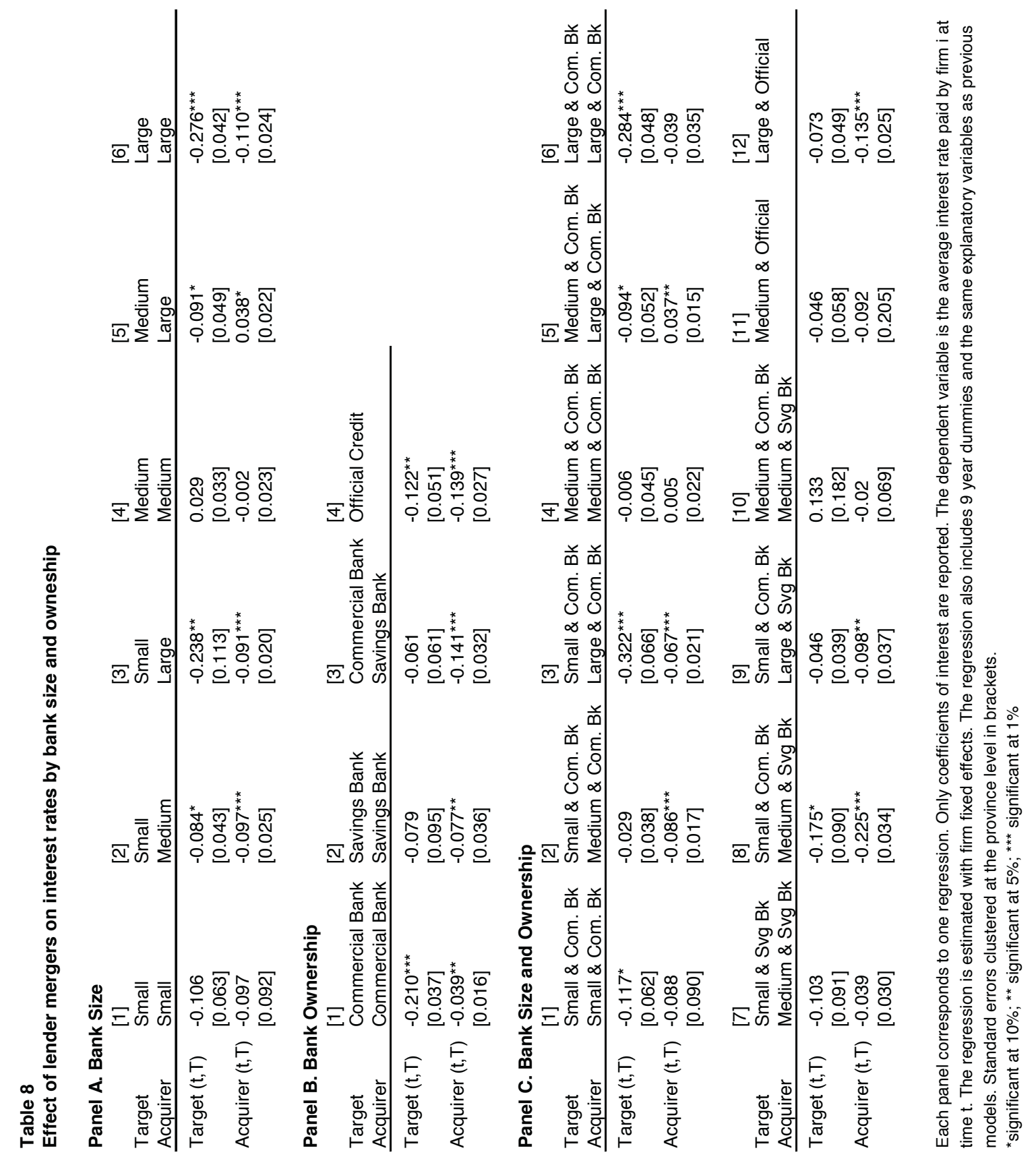


Table 9

Market overlap and change in market concentration

Panel A. In and out-of market mergers

\begin{tabular}{llll} 
& {$[1]$} & {$[2]$} & {$[3]$} \\
& In-market & Out-of-market & Other mergers \\
\hline Target $(\mathrm{t}, \mathrm{T})$ & $-0.207^{* * *}$ & $-0.100^{* *}$ & 0.088 \\
& {$[0.036]$} & {$[0.043]$} & {$[0.094]$} \\
Acquirer $(\mathrm{t}, \mathrm{T})$ & $-0.064^{* * *}$ & $-0.249^{*}$ & $-0.097^{* *}$ \\
& {$[0.023]$} & {$[0.129]$} & {$[0.040]$}
\end{tabular}

Panel B. Market concentration

\begin{tabular}{|c|c|c|}
\hline B.1. Small & $\Delta \mathrm{HHI} \geq 50$ & $\Delta \mathrm{HHI}<50$ \\
\hline Target $(\mathrm{t}, \mathrm{T})$ & $\begin{array}{l}-0.147^{* *} \\
{[0.063]}\end{array}$ & $\begin{array}{l}-0.181^{* * *} \\
{[0.035]}\end{array}$ \\
\hline Acquirer $(\mathrm{t}, \mathrm{T})$ & $\begin{array}{l}-0.050^{* *} \\
{[0.023]}\end{array}$ & $\begin{array}{l}-0.089^{* * *} \\
{[0.019]}\end{array}$ \\
\hline B.2. Moderate & $\Delta \mathrm{HHI} \geq 100$ & $\Delta \mathrm{HHI}<100$ \\
\hline Target $(\mathrm{t}, \mathrm{T})$ & $\begin{array}{l}-0.148^{* * *} \\
{[0.053]}\end{array}$ & $\begin{array}{l}-0.194^{* * *} \\
{[0.035]}\end{array}$ \\
\hline Acquirer $(\mathrm{t}, \mathrm{T})$ & $\begin{array}{l}-0.040^{*} \\
{[0.023]}\end{array}$ & $\begin{array}{l}-0.094^{* * *} \\
{[0.018]}\end{array}$ \\
\hline B.3. Large & $\Delta \mathrm{HHI} \geq 200$ & $\Delta \mathrm{HHI}<200$ \\
\hline Target $(\mathrm{t}, \mathrm{T})$ & $\begin{array}{l}-0.129 \\
{[0.116]}\end{array}$ & $\begin{array}{l}-0.202^{* * *} \\
{[0.033]}\end{array}$ \\
\hline Acquirer $(\mathrm{t}, \mathrm{T})$ & $\begin{array}{l}0.041 \\
{[0.030]}\end{array}$ & $\begin{array}{l}-0.103^{* * *} \\
{[0.017]}\end{array}$ \\
\hline
\end{tabular}

Panel C. In-market mergers and market concentration

[1] [2] [3] [4]

In-market \& $\Delta \mathrm{HHI} \geq 100 \quad$ In-market $\& \Delta \mathrm{HHI}<100 \quad$ Out-of-market Other mergers

$\begin{array}{lllll}\text { Target }(\mathrm{t}, \mathrm{T}) & -0.149^{* * *} & -0.205^{\star * *} & -0.104^{\star *} & 0.098 \\ & {[0.051]} & {[0.038]} & {[0.040]} & {[0.092]} \\ \text { Acquirer }(\mathrm{t}, \mathrm{T}) & -0.014 & -0.064^{* *} & -0.253^{*} & -0.084^{\star *} \\ & {[0.025]} & {[0.029]} & {[0.127]} & {[0.039]}\end{array}$

Each panel corresponds to one regression. Only coefficients of interest are reported. The dependent variable is the average interest rate paid by firm $i$ at time $t$. The regression is estimated with firm fixed effects. The regression also includes 9 year dummies and the same explanatory variables as previous models. Standard errors clustered at the province level in brackets.

*significant at $10 \%$; ** significant at $5 \%$; ${ }^{* * *}$ significant at $1 \%$ 


\section{European Central Bank Working Paper Series}

For a complete list of Working Papers published by the ECB, please visit the ECB's website (http://www.ecb.europa.eu).

904 "Does money matter in the IS curve? The case of the UK" by B. E. Jones and L. Stracca, June 2008.

905 "A persistence-weighted measure of core inflation in the euro area" by L. Bilke and L. Stracca, June 2008.

906 "The impact of the euro on equity markets: a country and sector decomposition" by L. Cappiello, A. Kadareja and S. Manganelli, June 2008.

907 "Globalisation and the euro area: simulation based analysis using the New Area Wide Model" by P. Jacquinot and R. Straub, June 2008.

908 "3-step analysis of public finances sustainability: the case of the European Union" by A. Afonso and C. Rault, June 2008.

909 "Repo markets, counterparty risk and the 2007/2008 liquidity crisis" by C. Ewerhart and J. Tapking, June 2008.

910 "How has CDO market pricing changed during the turmoil? Evidence from CDS index tranches" by M. Scheicher, June 2008.

911 "Global liquidity glut or global savings glut? A structural VAR approach” by T. Bracke and M. Fidora, June 2008.

912 "Labour cost and employment across euro area countries and sectors" by B. Pierluigi and M. Roma, June 2008.

913 "Country and industry equity risk premia in the euro area: an intertemporal approach" by L. Cappiello, M. Lo Duca and A. Maddaloni, June 2008.

914 "Evolution and sources of manufacturing productivity growth: evidence from a panel of European countries" by S. Giannangeli and R. Gómez-Salvador, June 2008.

915 "Medium run redux: technical change, factor shares and frictions in the euro area" by P. McAdam and A. Willman, June 2008.

916 "Optimal reserve composition in the presence of sudden stops: the euro and the dollar as safe haven currencies" by R. Beck and E. Rahbari, July 2008.

917 “Modelling and forecasting the yield curve under model uncertainty" by P. Donati and F. Donati, July 2008.

918 "Imports and profitability in the euro area manufacturing sector: the role of emerging market economies" by T. A. Peltonen, M. Skala, A. Santos Rivera and G. Pula, July 2008.

919 "Fiscal policy in real time" by J. Cimadomo, July 2008.

920 "An investigation on the effect of real exchange rate movements on OECD bilateral exports" by A. Berthou, July 2008.

92I "Foreign direct investment and environmental taxes" by R. A. De Santis and F. Stähler, July 2008.

922 "A review of nonfundamentalness and identification in structural VAR models" by L. Alessi, M. Barigozzi and M. Capasso, July 2008.

923 "Resuscitating the wage channel in models with unemployment fluctuations" by K. Christoffel and K. Kuester, August 2008. 
924 "Government spending volatility and the size of nations" by D. Furceri and M. Poplawski Ribeiro, August 2008.

925 "Flow on conjunctural information and forecast of euro area economic activity" by K. Drechsel and L. Maurin, August 2008.

926 "Euro area money demand and international portfolio allocation: a contribution to assessing risks to price stability” by R. A. De Santis, C. A. Favero and B. Roffia, August 2008.

927 “Monetary stabilisation in a currency union of small open economies” by M. Sánchez, August 2008.

928 “Corporate tax competition and the decline of public investment” by P. Gomes and F. Pouget, August 2008.

929 "Real convergence in Central and Eastern European EU Member States: which role for exchange rate volatility?" by O. Arratibel, D. Furceri and R. Martin, September 2008.

930 "Sticky information Phillips curves: European evidence" by J. Döpke, J. Dovern, U. Fritsche and J. Slacalek, September 2008.

93। “International stock return comovements” by G. Bekaert, R. J. Hodrick and X. Zhang, September 2008.

932 "How does competition affect efficiency and soundness in banking? New empirical evidence" by K. Schaeck and M. Čihák, September 2008.

933 "Import price dynamics in major advanced economies and heterogeneity in exchange rate pass-through" by S. Dées, M. Burgert and N. Parent, September 2008.

934 “Bank mergers and lending relationships" by J. Montoriol-Garriga, September 2008. 


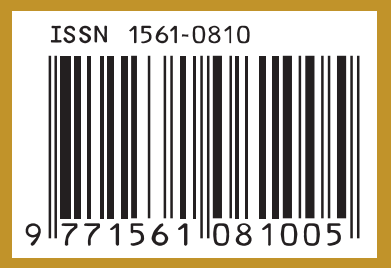

